\title{
Genome-wide screening of novel RT-qPCR reference genes for study of GLRaV-3 infection in wine grapes and refinement of an RNA isolation protocol for grape berries
}

\author{
Yashu Song ${ }^{1^{*}} \mathbb{D}$, Robert H. Hanner ${ }^{2}$ and Baozhong Meng ${ }^{1}$
}

\begin{abstract}
Background: Grapevine, as an essential fruit crop with high economic values, has been the focus of molecular studies in diverse areas. Two challenges exist in the grapevine research field: (i) the lack of a rapid, user-friendly and effective RNA isolation protocol for mature dark-skinned berries and, (ii) the lack of validated reference genes that are stable for quantification of gene expression across desired experimental conditions. Successful isolation of RNA with sufficient yield and quality is essential for downstream analyses involving nucleic acids. However, ripe berries of darkskinned grape cultivars are notoriously challenging in RNA isolation due to high contents of polyphenolics, polysaccharides, RNase and water.

Results: We have optimized an RNA isolation protocol through modulating two factors at the lysis step that could impact results of RNA isolation - 2-ME concentration and berry mass. By finding the optimal combination among the two factors, our refined protocol was highly effective in isolating total RNA with high yield and quality from whole mature berries of an array of dark-skinned wine grape cultivars. Our protocol takes a much shorter time to complete, is highly effective, and eliminates the requirement for hazardous organic solvents. We have also shown that the resulting RNA preps were suitable for multiple downstream analyses, including the detection of viruses and amplification of grapevine genes using reverse transcription-polymerase chain reaction (RT-PCR), gene expression analysis via quantitative reverse transcription PCR (RT-qPCR), and RNA Sequencing (RNA-Seq). By using RNA-Seq data derived from Cabernet Franc, we have identified seven novel reference gene candidates (CYSP, NDUFS8, YLS8, EIF5A2, Gluc, GDT1, and EF-Hand) with stable expression across two tissue types, three developmental stages and status of infection with grapevine leafroll-associated virus 3 (GLRaV-3). We evaluated the stability of these candidate genes together with two conventional reference genes (actin and NAD5) using geNorm, NormFinder and BestKeeper. We found that the novel reference gene candidates outperformed both actin and NAD5. The three most stable reference genes were CYSP, NDUFS8 and YSL8, whereas actin and NAD5 were among the least stable. We further tested if there would be a difference in RT-qPCR quantification results when the most stable (CYSP) and the least stable (actin and NAD5) genes were used for normalization. We concluded that both actin and NAD5 led to erroneous RT-qPCR results in determining the statistical significance and fold-change values of gene expressional change.
\end{abstract}

*Correspondence: yashu@uoguelph.ca

${ }^{1}$ Department of Molecular and Cellular Biology, University of Guelph, 50

Stone Road, Guelph, ON N1G2W1, Canada

Full list of author information is available at the end of the article original author(s) and the source, provide a link to the Creative Commons licence, and indicate if changes were made. The images or other third party material in this article are included in the article's Creative Commons licence, unless indicated otherwise in a credit line to the material. If material is not included in the article's Creative Commons licence and your intended use is not permitted by statutory regulation or exceeds the permitted use, you will need to obtain permission directly from the copyright holder. To view a copy of this licence, visit http://creativecommons.org/licenses/by/4.0/. The Creative Commons Public Domain Dedication waiver (http://creativeco mmons.org/publicdomain/zero/1.0/) applies to the data made available in this article, unless otherwise stated in a credit line to the data. 
Conclusions: We have formulated a rapid, safe and highly effective protocol for isolating RNA from recalcitrant berry tissue of wine grapes. The resulting RNA is of high quality and suitable for RT-qPCR and RNA-Seq. We have identified and validated a set of novel reference genes based on RNA-Seq dataset. We have shown that these new reference genes are superior over actin and NAD5, two of the conventional reference genes commonly used in early studies.

Keywords: Vitis vinifera, Wine grapes, Viruses, Grapevine leafroll-associated virus 3, RNA-Seq, RT-qPCR, Gene expression and normalization, geNorm, NormFinder, BestKeeper, Virus-host interactions

\section{Background}

Grapevine (Vitis spp.) is a major fruit crop with global cultivation of over 7.4 million hectares. It has high economic value in producing a variety of products, including table fruit, juice, seed oil and wine [1]. Over the past few decades, this woody fruit crop has been the focus of diverse molecular studies, including responses to abiotic or biotic stresses, developmental changes and impact on berry quality, and host-pathogen interactions. Studies often involved using nucleic-acid based assays such as RT-PCR and RT-qPCR [2-11], or highthroughput sequencing (HTS) such as microarray and RNA-Sequencing (RNA-Seq) [12-14]. While these are powerful technologies that deliver insights to our understanding of grapevine molecular biology, success of the analyses is heavily dependent on the integrity and yield of total RNA isolated from grapevine tissues. RNA isolation has been one of the major technical challenges for studies of woody plants, especially grapevine, due to the abundant presence of secondary metabolites such as polyphenols and polysaccharides [15]. This issue is especially acute for berries. Berries of dark-skinned grape cultivars, especially at veraison (i.e., the stage where berries start to change colour and soften) through harvest, are particularly problematic when it comes to the isolation of high quality RNA. Compared to other organs of grapevine, veraison and ripe dark-skinned berries have a low concentration of nucleic acids, but high levels of water content, soluble solids (e.g., glucose and fructose), lipids, and RNases, on top of the already abundant polyphenolic compounds and polysaccharides present in the tissues $[15,16]$. High levels of these compounds interfere with RNA isolation, leading to the extracted RNA being low in concentration and poor in integrity $[16,17]$, making downstream analyses involving berries essentially impossible.

Extensive efforts have been made in the past to resolve this issue by developing RNA isolation protocols suitable for dark-skinned grapevine berries. However, these methods mostly involved the use of hazardous organic solvents such as phenol and chloroform [15, 17-22]. In addition, some of the methods are tedious and timeconsuming as the protocols included many steps and long extraction time spanning two days or more. These protocols require repetitive centrifugations at controlled temperatures, overnight precipitation, and as a result, only a limited number of samples can be processed at a time [15, 17-22]. Some methods involved the extraction of total RNA from seeds, skin, or flesh of berries separately $[15,21,23]$, which may not be applicable for downstream analyses that target whole berries, such as transcriptomic analysis of the whole berry under various biotic and abiotic conditions. For dark-skinned wine grapes with high values for wine-making and for the purpose of molecular studies, the lack of a robust RNA isolation protocol would hinder future molecular analyses concerning any berry-related questions. Development of a rapid, user-friendly and highly effective protocol that can be used for large-scale isolation of quality RNA from whole mature berries of dark-skinned grapevine cultivars is much needed.

Besides the challenges in RNA isolation, another problem constantly faced by grapevine researchers has been the lack of properly validated reference genes in RTqPCR studies. Gene expression analysis via RT-qPCR is an essential approach taken by researchers to increase understanding of the dynamic molecular interplay in grapevine under various adverse conditions. Compared to conventional RT-PCR, RT-qPCR provides a more sensitive and accurate measurement of target transcripts [24]. As such, RT-qPCR has been used extensively in various gene expression studies [4, 25-29]. However, reliable quantification of gene expression using RT-qPCR is dependent on various factors, including the integrity and yield of RNA, efficiency of cDNA synthesis and PCR amplification, primer efficiency, difference in the initial sample amount, and variation in transcriptional activity in the investigated cells and tissues [30-32]. Reference genes, whose expression levels remain constant, at least ideally, regardless of experimental treatment, developmental stages, or type of tissues or cells, were therefore used as an internal control to normalize the variations of gene expression data brought by these variables in RTqPCR analysis [30, 33-36].

Selection of proper reference genes that exhibit minimal changes in expression during a specific experiment is crucial for the accuracy of RT-qPCR analysis. However, past studies often selected reference genes based 
on assumptions rather than evidence [35, 37]. Genes involved in basic cellular processes, such as cell structure and primary metabolism, referred to as 'housekeeping genes', were presumed to have stable expression across tissues, cell types, and experimental conditions. These genes were of primary choice as RT-qPCR reference genes $[15,38]$. Some of the most commonly used reference genes as reported in the literature include $18 \mathrm{~S}$ rRNA, glyceraldehyde-3-phosphate dehydrogenase $(\mathrm{GAPDH})$, translation elongation factor $1 \alpha(\mathrm{EF}-1 \alpha)$, ubiquitin (UBQ), actin (ACT), alpha-tubulin ( $\alpha-\mathrm{TUB})$, and $\beta$-TUB [38-41]. However, these 'presumed' conventional reference genes have been discredited by an increasing number of studies. A high degree of expressional variation among these genes was reported in diverse plant species, including Arabidopsis [38], rice [42], maize [43], tomato [44, 45], wheat [46], and poplar [47]. In addition, it has become clear that there are no universal reference genes that would work for all plant species, all tissue types, and different experimental conditions [30, 35, 48]. Therefore, it is necessary to first identify and validate reference genes with low expressional variation for each species of interest and for the intended research, before carrying out gene expression analysis with RT-qPCR [35, $49,50]$.

A similar situation exists for gene expression and quantification studies involving grapevine. A majority of RT-qPCR studies pertaining to grapevine adopted a literature-based approach when searching for reference gene candidates $[15,37,51-55]$. Consequently, the identified candidates circled back to the 'presumed' conventional reference genes mentioned above; yet, their expressional stability remains questionable. The advent of RNA-Seq technologies has enabled genome-wide identification of reference genes with little or no expressional fluctuation in a designed experimental system. These novel reference genes were more credible than their conventional counterparts, as their identified stability was based on transcriptomic data validation, rather than presumption. Studies have used transcriptomic data derived from RNA-Seq or microarray to identify novel reference genes stably expressed in a range of plant species, including Arabidopsis [38], barley [56], wheat [46, 57, 58], soybean $[39,59]$, maize [60], tomato [44, 45], upland cotton [61] and poplar [47]. All of these novel reference genes were proven to have higher stability than the conventional reference genes described above [38, 45-47, 57-60, 62, 63]. For example, using transcriptomic data, Czechowski et al. [38] identified five novel reference genes: TIP41like, two subunits of PP2A (At1g13320 and At1g59830), At4g33380, and a SAND family gene. Importantly, these novel reference genes outperformed conventional reference genes including ACT2, TUB6, EF- $1 \alpha$, UBQ10, and
GAPDH by demonstrating less expressional fluctuation under various conditions tested (e.g., genotype, developmental stages, organ types, biotic, and abiotic stresses). Furthermore, these novel reference genes had higher stability rankings when examined by the bioinformatics tool, geNorm [38]. Two independent studies have used microarray data to search for the most stable novel reference genes of wine grape cultivars under biotic stress (i.e., infection with Plasmopara viticola and Botrytis cinerea) [64], or abiotic stress (water and heat stress) [65]. Two other studies have used RNA-Seq data to identify novel reference genes in berries of table grapes across different phenological stages and under abiotic stress $[66,67]$. However, no studies have used genome-wide screening to identify reference genes with stable expression across viral infection, tissue types and phenological stages.

A peculiarity of grapevine is that it is susceptible to a wide spectrum of viral pathogens. More than 80 viruses and virus-like agents have been documented to infect grapevine [68], constituting the most substantial group of viruses that infect a single plant crop. Grapevine leafroll-associated virus 3 (GLRaV-3) is a positive-sense, single-stranded RNA (ssRNA) virus of the Ampelovirus genus within the family Closteroviridae [69]. It is one of the major grapevine viruses with a worldwide prevalence and is the main agent associated with grapevine leafroll disease (GLRD); the most prevalent and destructive viral disease of grapevine that afflicts global grape and wine production [70-72]. Infection with GLRaV-3 can result in significant yield reduction and altered fruit chemistry that negatively impact the quality of fresh fruits, juice and wine, as well as the profitability and lifespan of vineyards [71, 73]. There are limited studies on the impact of GLRaV-3 infection on the global gene expression of grapevine, which limits our understanding of the pathogenesis and pathology of GLRaV-3 as well as the complex biology of GLRD. Preliminary results revealed that GLRaV-3 infection induced up-regulation of sugar transporter genes in leaves but down-regulation in berries at veraison and harvest $[5,13]$. In addition, genes of flavonoid biosynthetic pathway were differentially regulated in leaves and berries of dark-skinned cultivars infected with GLRaV-3, leading to de novo synthesis of anthocyanins in GLRaV-3-infected leaves - hence, the reddish-to-purple discolouration of leaf blades [4]. In contrast, GLRaV-3 infection led to reduced levels of flavonoids in berries including anthocyanins, proanthocyanidins, and flavonols [5, 74-76]. Nevertheless, we are still at the exploration phase of understanding molecular mechanisms underlying the pathological impacts of GLRaV-3 on grapevine. Identification of reference genes whose expression remains stable in 
GLRaV-3-infected grapevine will open doors for future research on GLRaV-3-host interactions at transcriptomic level.

In this study, we aimed to address two key issues related to current research on gene expression and virushost interactions in grapevine. First, we have developed an optimized RNA isolation protocol suitable for mature berries of dark-skinned wine grape cultivars. This protocol produced a much higher yield of RNA with high integrity, making it suitable for downstream analyses such as RNA-Seq and RT-qPCR. This is the first total RNA isolation protocol that can be used on whole ripe red berries without the need for hazardous organic solvents and can be completed within a much shorter time frame than the other protocols currently available. Second, using RNA-Seq data derived from two tissue types and three developmental stages of Cabernet Franc and a holistic bioinformatics approach, we have identified a set of novel reference genes whose expression is stable in different tissues, developmental stages and under viral infections.

\section{Material and methods}

\section{Sample collection}

Leaves and berries of Vitis vinifera cv. Cabernet Franc (clone 210 grafted on rootstock 3309) were collected in 2019 from a commercial vineyard located in Niagara Peninsula, Ontario, Canada. Prior to sample collection, viral infection status of vines was tested by RT-PCR using primers specific for a set of grapevine viruses that are included in the international certification programs, including five viruses associated with grapevine leafroll (GLRaV-1, -2, -3, -4, -7), three involved in rugose wood disease complex (GRSPaV, GVA, and GVB), four involved in the infectious degeneration and decline (GFLV, ArMV, TRSV, and TomRSV), plus GRBaV and GPGV [9].

For sample collection, fully expanded mature leaves were collected. The maturity of leaf samples was judged by chlorophyll content via SPAD meter [77]. SPAD meter emits both red light with $650 \mathrm{~nm}$ wavelength and infrared light of $940 \mathrm{~nm}$ [78]. Leaf chlorophyll absorbs red light but not infrared light. Therefore, by calculating the difference between transmittance values of $950 \mathrm{~nm}$ and $650 \mathrm{~nm}$, the SPAD meter generates a chlorophyll content index (CCI) that is proportional to the chlorophyll content of the leaf [78]. For each vine (biological replicate), two fully expanded leaves with the highest CCI compared to the rest of the leaves of the same shoot were collected; berries of the same cluster were collected. Leaf and berry samples were collected from three vines tested positive for GLRaV-3 (three GLRaV-3-infected biological replicates) and three vines tested negative for the virus (three control biological replicates). Leaf samples were collected from each of the six vines at two developmental stages, E-L 31 (marked by pea-sized berries) and E-L 35 (veraison), based on the modified Eichhorn and Lorenz (E-L) system proposed by Coombe [79, 80]. Berry samples were collected at three developmental stages, E-L 31, E-L 35, and E-L 38 (harvest). Ripe berries at E-L 38 were collected from additional nine dark-skinned wine grape cultivars, including $V$. vinifera (Pinot Noir, Pinot Meunier, Gamay, Cabernet Sauvignon, and Merlot) and French-American hybrid grapes (De Chaunac, Marechal Foch, Chambourcin, and Baco Noir). All samples were immediately frozen in liquid nitrogen, then stored in dry ice for transportation. All samples were ground into fine powdery in liquid nitrogen using a mortar and a pestle, then stored under $-80^{\circ} \mathrm{C}$ until further analysis.

\section{Total RNA isolation}

RNA isolation protocol was optimized by adjusting two parameters at the lysis step: concentration of $\beta$-mercaptoethanol (2-ME) and sample mass. For leaf samples of both developmental stages and young berries at E-L 31, $50 \mathrm{mg}$ of leaf sample and $100 \mathrm{mg}$ of berry sample were used for total RNA isolation using the method developed recently in our lab [81]. For berries collected at E-L 35 and E-L 38, total RNA was isolated using the Spectrum ${ }^{\mathrm{TM}}$ Plant Total RNA Kit (Sigma-Aldrich) with the following modifications. Different amounts of 2-ME were added to the lysis buffer to test the effects on both the yield and quality of the total RNA. Also, the ground berry tissue powder used for RNA isolation was increased in increments. Tissue powders in the modified lysis buffer were subjected to further and vigorous grinding using a mortar and a pestle. The rest of RNA isolation steps followed the instruction from the vendor, except for the last washing step, where RNA-binding columns were washed three times instead of two.

Total RNA concentration, OD260/280 ratio, and OD260/230 ratio were assessed by NanoDrop ND-1000 spectrophotometer (Thermo Fisher Scientific, Wilmington, DE, USA). RNA integrity of all samples was verified through $1 \%$ agarose gel electrophoresis followed by staining with ethidium bromide. RNA integrity of leaf and berry samples collected from Cabernet Franc was further validated using Agilent 2100 Bioanalyzer via Novogene (Sacramento, CA, USA).

\section{RT-PCR}

To examine the robustness of our optimized RNA isolation protocol in downstream analyses, total RNAs of Cabernet Franc (both leaf and berry samples) were used in RT-PCR with GLRaV-3-specific primers designed in our lab [2]. Total RNAs isolated from ripe berries of additional nine dark-skinned wine grape varieties (the infection status for GLRaV-3 was unknown) were used 
in RT-PCR for the amplification of phytoene desaturase (PDS) gene using primers PDS-853F and PDS-1252R, with an expected amplicon size of $500 \mathrm{bp}$. cDNA of all samples was synthesized with $5 \mu \mathrm{g}$ of total RNA using Applied Biosystem High-Capacity cDNA Reverse Transcription Kit (Thermo Fisher Scientific, Carlsbad, CA, USA) according to manufacturer's instructions.

\section{RNA-Seq analysis and identification of candidate reference genes}

Total RNAs of leaf and berry samples from Cabernet Franc were sent to Novogene (Sacramento, CA, USA) for 150 bp paired-end mRNA sequencing on the NovaSeq 6000 platform. Raw RNA-Seq data was trimmed by Trim Galore! [82] to remove adaptor sequences and low-quality reads, followed by quality evaluation using FastQC [83]. Reads were mapped to the grapevine reference genome [ $V$. vinifera $\mathrm{cv}$. PN40024 [84] and transcript expressions were normalized to Transcripts Per Million (TPM) using Salmon [85].

Genes that were non-differentially expressed across the three developmental stages (E-L 31, 35, and 38), infectious status (tested positive or negative for GLRaV-3) and tissue types (leaf and berry) were identified as candidate reference genes using the TPM method described by Li et al. [86]. For detailed explanation of the TPM method, readers are referred to $\mathrm{Li}$ et al. [86]. Briefly, all four criteria below must be met for a gene to be considered a candidate: (1) relatively high levels of expression $\left(\right.$ mean $\left.\left[\log _{2}\left(\mathrm{TPM}_{\text {gene }}\right)\right]>5\right)$; (2) low expressional variance across samples (standard-deviation $\left[\log _{2}\left(\mathrm{TPM}_{\text {gene }}\right)\right]<1$ ); (3) no sudden differential expression in any single sample $\left(\log _{2}\left(\mathrm{TPM}_{\text {gene }}\right)-\right.$ mean $\left.\left[\log _{2}\left(\mathrm{TPM}_{\text {gene }}\right)\right]<|2|\right)$; and $(4)$ genes meeting all of the above criteria and shared by both leaf and berry RNA-Seq datasets were chosen as the coreset of reference gene candidates for our RT-qPCR analysis. The core-set reference gene candidates were further ranked by coefficient of variance $(\mathrm{CV}=$ standard deviation divided by mean) from the lowest to the highest. The top seven candidates with the lowest $C V$ values were selected for further validation of their expressional stability by downstream statistical approaches.

\section{Function enrichment analysis}

Functional enrichment analysis and pathway analysis were conducted to further understand the biological functions of the identified core-set candidate reference genes. Gene ontology (GO) and Kyoto Encyclopedia of Genes and Genomes (KEGG) enrichment analysis of the core-set of candidate reference genes were performed using DAVID with the default algorithm using an FDR cutoff at 0.01 [87]. GO consortium vocabularies were used for gene annotation and for grouping of the core-set of candidate reference genes at three levels, Biological Process (BP), Molecular Functions (MF), and Cellular Component (CC). KEGG annotations were used for pathway enrichment analysis.

\section{Validation of select candidate reference genes}

RT-qPCR was performed on each of the seven selected novel reference gene candidates. Actin and NAD5, two of the conventionally used reference genes reported as the most suitable reference genes from an earlier study involving grapevines infected with GLRaV-3 [4], were included here in order to compare their expression stability with the seven novel reference gene candidates identified in this work (Table 1). Expression stability of these nine candidate reference genes was evaluated using three independent analytical methods: geNorm [33], NormFinder [30], and BestKeeper [88].

Target-specific primers were designed using PrimerBLAST [89] with a melting temperature $(\mathrm{Tm})$ between 59 and $63{ }^{\circ} \mathrm{C}$, primer length of $20-22$ nucleotides, and amplicon size between 175 and 206 bp (Table 1). RTqPCR was conducted in a 96-well plate using StepOnePlus Real-Time PCR System (Applied Biosystems, Foster City, CA, USA). Each $15 \mu \mathrm{L}$ reaction contained $5 \mu \mathrm{L}$ of fivefold diluted cDNA, $7.5 \mu \mathrm{L}$ of Bio-Rad SoAdvanced ${ }^{\mathrm{TM}}$ Universal IT SYBR Green Supermix and $0.6 \mu \mathrm{L}$ each of $10 \mu \mathrm{M}$ primers. Reactions were run using cycling parameters of $98^{\circ} \mathrm{C}$ for $3 \mathrm{~min}, 40$ cycles of $98^{\circ} \mathrm{C}$ for $10 \mathrm{~s}$ and $60{ }^{\circ} \mathrm{C}$ for $30 \mathrm{~s}$, followed by a single cycle at $95^{\circ} \mathrm{C}$ for $15 \mathrm{~s}$, $75^{\circ} \mathrm{C}$ for $1 \mathrm{~min}$, and $95^{\circ} \mathrm{C}$ for $15 \mathrm{~s}$ for melt curve analysis. RT-qPCR analysis for each sample was performed in triplicate. No-template controls were included for each RTqPCR analysis. For each gene, the melting curve analysis was carried out to verify the specificity of amplification. Amplification efficiency (E) of each candidate reference gene/primer set was calculated based on a standard curve generated using fivefold dilution series $(1 ; 1: 5 ; 1: 25$; $1: 125 ; 1: 625)$. The standard curve was generated using StepOnePlus Software v2.3 (Applied Biosystems, Foster City, CA, USA). All primer pairs had amplification efficiency within the acceptable range, from 92.1 to $104.7 \%$ (Table 1). The same batch of diluted cDNA obtained from each biological replicate (control and GLRaV-3-infected leaf at E-L 31 and 35, control and GLRaV-3-infected berry at E-L 31, 35 and 38) was used as the template for RT-qPCR analysis to avoid potential impact of inconsistency in reverse transcription on downstream quantification of candidate reference genes.

\section{Results}

Leaf and berry sampling conditions

Fully expanded mature leaves of vines (control and GLRaV-3-infected) at stage E-L 31 and E-L 35 and whole 
Table 1 Genes and primer sets used for RT-qPCR

\begin{tabular}{|c|c|c|c|c|c|}
\hline Gene abbreviation & Accession no. & NCBI gene description & Primer sequence $\left(5^{\prime}-3^{\prime}\right)$ & $\begin{array}{l}\text { Amplicon } \\
\text { size (bp) }\end{array}$ & $\begin{array}{l}\text { Amplification } \\
\text { efficiency (E) }\end{array}$ \\
\hline EF-Hand & NM_001280964.1 & EF-hand calcium-binding protein & $\begin{array}{l}\text { F: TTTGACAGGGACCGTAGTGG } \\
\text { R: GTCAGCCCCTTTACCGTGAG }\end{array}$ & 188 & 98.25 \\
\hline GDT1 & XM_019218145.1 & GDT1-like protein 5 & $\begin{array}{l}\text { F: GGCTGCTCCAAACCTGTTGTC } \\
\text { R: ACCTTGCTATCCCCTTTGGC }\end{array}$ & 192 & 104.68 \\
\hline CYSP & NM_001281060.1 & Cysteine protease & $\begin{array}{l}\text { F: AAAATCAGGGTTCGTGTGGGTC } \\
\text { R: GCAGTGTTCATCAGCCCACC }\end{array}$ & 190 & 96.79 \\
\hline NDUFS8 & XM_003631606.3 & $\begin{array}{l}\text { NADH dehydrogenase [ubiquinone] iron- } \\
\text { sulfur protein } 8 \text { (mitochondrial) }\end{array}$ & $\begin{array}{l}\text { F: CCGTAGAACGACCAGGTACGAC } \\
\text { R: GCAATCTCGGTTTCCCAGCG }\end{array}$ & 189 & 94.66 \\
\hline EIF5A2 & XM_002285469.4 & $\begin{array}{l}\text { Eukaryotic translation initiation factor } \\
5 \mathrm{~A}-2\end{array}$ & $\begin{array}{l}\text { F: CCGCAAGAACGGCTACATCG } \\
\text { R: CGGGTAACATGTGGAACATCAC }\end{array}$ & 183 & 103.45 \\
\hline Gluc & XM_010651552.1 & Endo-1,3;1,4-beta-D-glucanase & $\begin{array}{l}\text { F: GCTTTTGCTGGGGTGCCAAG } \\
\text { R:TGTTTCACGAGTGCCGGTG }\end{array}$ & 175 & 95.74 \\
\hline YSL8 & XM_002283586.3 & Thioredoxin-like protein YLS8 & $\begin{array}{l}\text { F:TCAGGCGTGAAGAGAGAAAGC } \\
\text { R: AGCCAGAACTTCATCCATCTGC }\end{array}$ & 186 & 97.28 \\
\hline Actin & XM_002277287.4 & Actin 1 & $\begin{array}{l}\text { F: ATCAGGAAGGACCTCTATGG } \\
\text { R: ATCCACATCTGCTGGAAGG }\end{array}$ & 206 & 92.98 \\
\hline NAD5 & GU585873.1 & NADH dehydrogenase subunit 5 & $\begin{array}{l}\text { F: GATGCTTCTTGGGGCTTCTTGTT } \\
\text { R: CTCCAGTCACCAACATTGGCATAA }\end{array}$ & 181 & 92.08 \\
\hline UFGT & XM_010659535.2 & Anthocyanidin 3-O-glucosyltransferase 2 & $\begin{array}{l}\text { F: TCTTCCCTTCTGTGGTGCTTG } \\
\text { R:TTATTGAGCAGGGGTCCAACAG }\end{array}$ & 187 & 99.10 \\
\hline
\end{tabular}

Seven novel reference genes candidates identified from our own RNA-Seq data were EF-hand, GDT1, CYSP, NDUFS8, EIF5A2, Gluc, YSL8. Two conventional reference genes used by a past study, Gutha et al. [4] were actin and NAD5. UFGT, shown previously as a responsive gene whose expression was influenced by GLRaV-3 infection, was chosen in this study for RT-qPCR validation

berries of vines (control and GLRaV-3-infected) at E-L 31, E-L 35, and E-L 38 were collected for this study. No observable difference was found between leaves of control vines and those of GLRaV-3-infected vines at E-L 31 (Fig. 1). At E-L 35 stage, we observed typical GLRD symptoms in GLRaV-3-infected leaves, characterized by red to purple pigmentation of interveinal regions (Fig. 1). GLRD symptoms progressed as vines grew into E-L 38 (harvest), with more leaves showing symptoms and more evident discoloration together with the development of downward curling on margins of mature leaves (Fig. 1). No physiological difference was observed between berries from control vines and those from GLRaV-3-infected vines at either E-L 31, E-L 35, or E-L 38. Berries collected at E-L 31 were green and hard, as expected. Berries collected at E-L 35 were softened to touch compared to E-L 31; in addition, a portion of berries in the same cluster started to change colour from green to purple (Fig. 1). At E-L 38, ripe berries showed dark-purple colour (Fig. 1) and emitted strong aroma.

\section{The refined RNA isolation method yielded quality RNAs suitable for downstream assays}

Our lab had previously improved the Sigma kit and made it suitable for isolation of quality RNA from old grapevine leaves with GLRD symptoms by addition of $2.5 \%$ of polyvinylpyrrolidone (PVP-40) to the lysis buffer [81]. However, this modification failed to generate sufficient amounts of quality RNA from darkskinned berry samples. We further identified two additional factors as potential variables that would impact the quality and yield of total RNA for darkskinned berries: concentration of 2-ME and the amount of berry tissue used.

We first tested the 'baseline protocol' on ripe berries of Cabernet Franc using lysis buffer containing 1\% of 2-ME and $50 \mathrm{mg}$ of tissue, which was recommended by the vendor, and a modified lysis buffer (adding $2.5 \%$ PVP-40). Three biological replicates of ripe berries (i.e., berries collected from three vines) were used for each round of the test. NanoDrop results, including OD260/280 and OD260/230 ratios and RNA concentration $(\mathrm{ng} / \mu \mathrm{L})$, were recorded as the average of the three replicates. Very little RNA was obtained when the 'baseline protocol' was used (Additional file 1: Table S1, "Berry mass and 2-ME conc." sub-sheet). We then preliminarily assessed the association between RNA yield/ purity and the two variables identified in this study (berry mass and 2-ME concentration) using NanoDrop. We found that berry mass and 2-ME concentration were positively correlated with both the yield and purity of RNA from mature dark-skinned berry (Additional file 1: Table S1, "Berry mass and 2-ME conc." sub-sheet). Based on the trend given by NanoDrop 

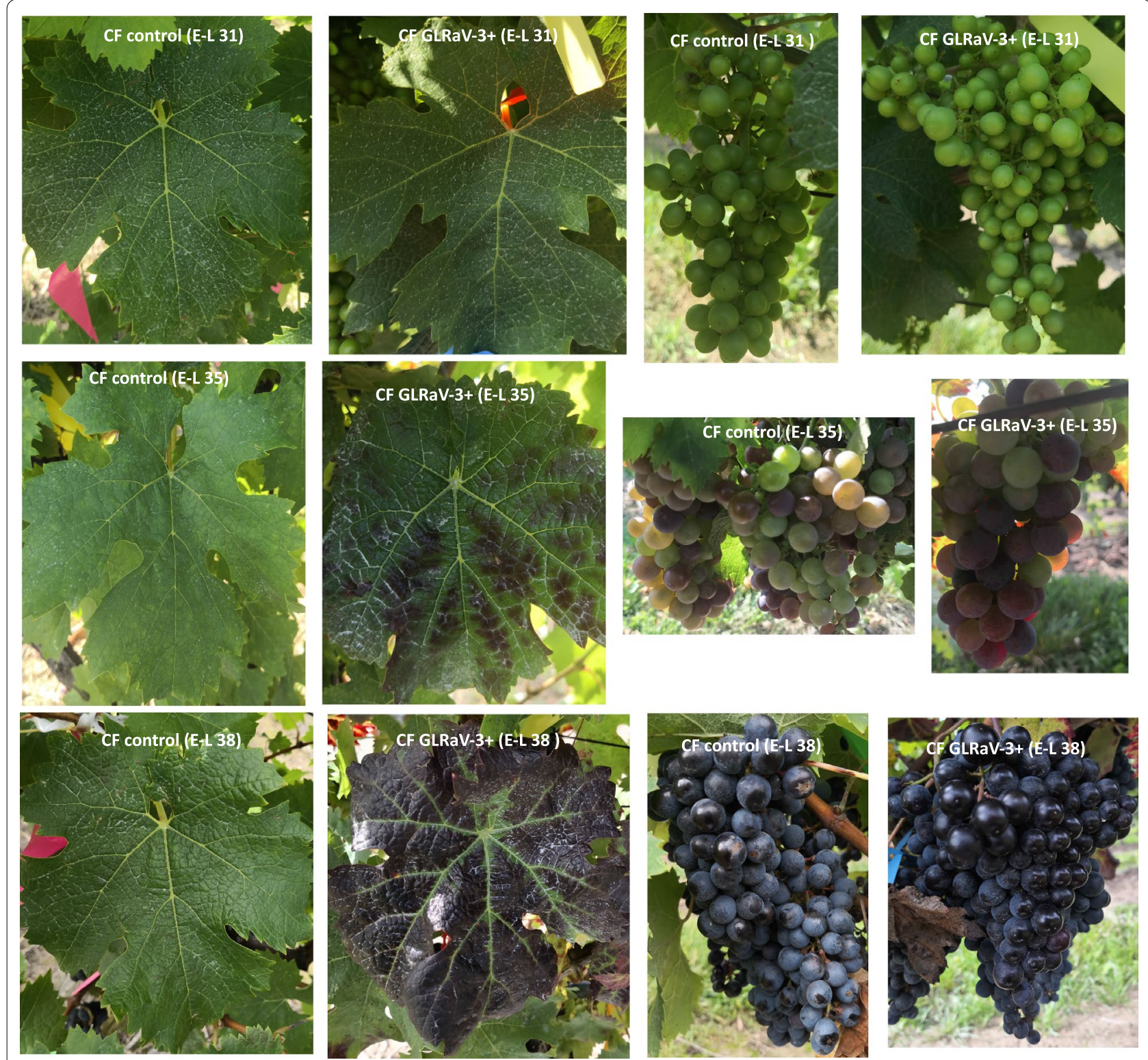

Fig. 1 Condition of leaf and berry of control and GLRaV-3-infected vines at stages E-L 31, E-L 35, and E-L 38

results, we have noted that increasing berry mass to $300-500 \mathrm{mg}$ and $2-\mathrm{ME}$ concentration to $2-3 \%$ at lysis step played a crucial role for optimal RNA isolation from dark-skinned berries (Additional file 1: Table S1, "Berry mass and 2-ME conc." sub-sheet)."

We further tested the effectiveness of RNA isolation involving the identified parameters (300 mg berry mass, $2 \%$ of 2 -ME, and $2.5 \%$ of PVP-40) on leaf and berry samples of Cabernet Franc at three different phenological stages (E-L 31, 35, and 38), as well as mature berries at E-L 38 of nine additional dark-skinned wine grape varieties, including five $V$. vinifera cultivars (Cabernet
Sauvignon, Pinot Noir, Pinot Meunier, Gamay, and Merlot) and four hybrids (Marechal Foch, De Chaunac, Chambourcin, and Baco Noir). A consistent OD260/280 ratio of $>2.0$ and OD260/230 ratio of $>1.9$, and satisfying RNA yields ranging from 68.1 to $295.7 \mathrm{ng} / \mu \mathrm{L}$ were obtained for total RNA extracted from both berry samples collected at veraison and harvest (Additional file 1: Table S1, "Cab. Franc leaf and berry" and "Other nine grapevine varieties" sub-sheets).

The integrity of total RNA preps was examined through gel electrophoresis. Results showed that the RNA preps from both leaf and berry samples of Cabernet Franc 

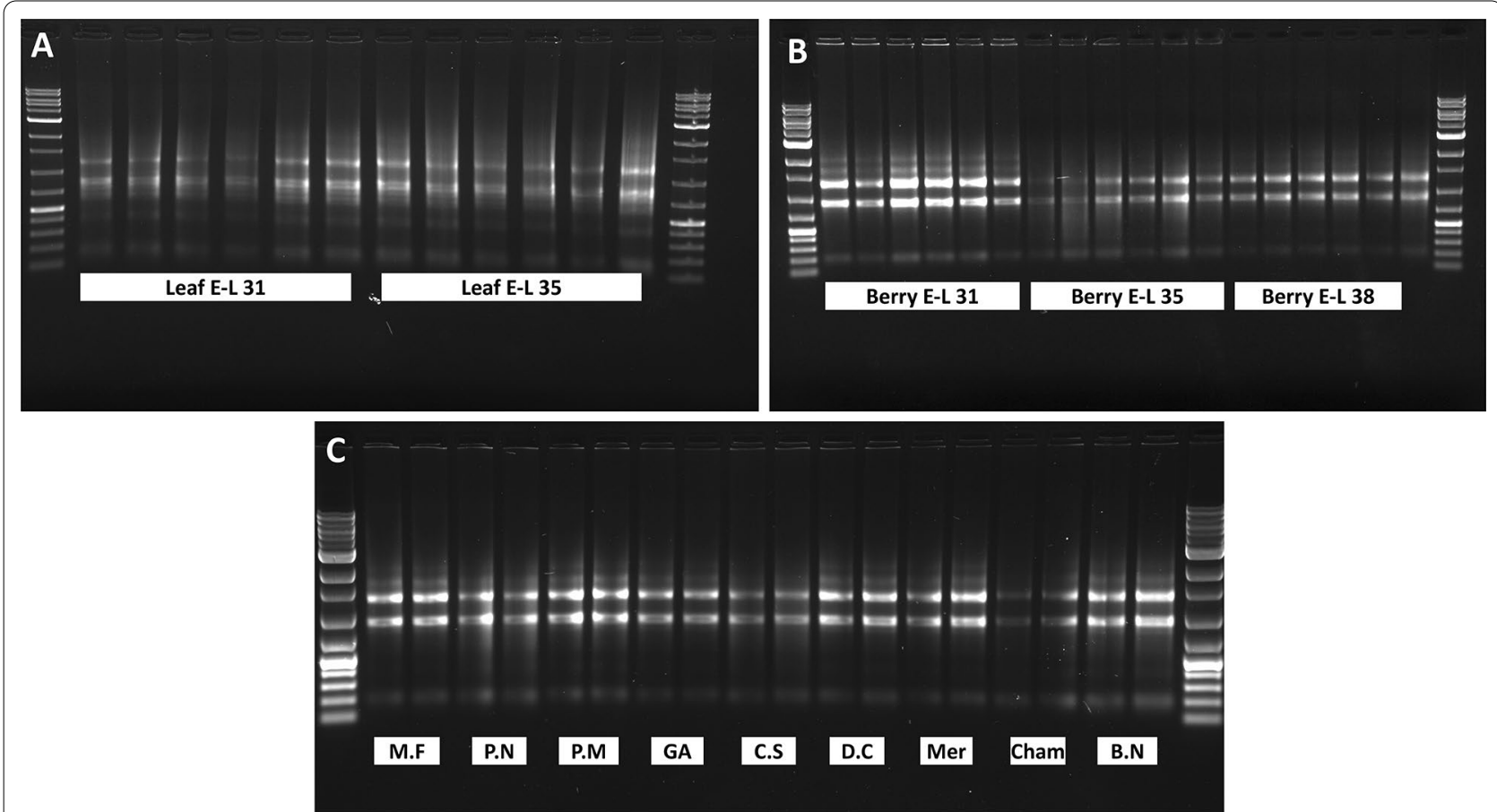

Fig. 2 Profile of total RNA samples through electrophoresis on 1\% agarose gels. A Total RNA extracted from leaf samples of Cabernet Franc collected at E-L 31 (six lanes on the left) and at E-L 35 (veraison) (six lanes to the right). B Total RNA extracted from berry samples of Cabernet Franc collected at E-L 31 (six lanes on the left), E-L 35 (six lanes in the middle), and E-L 38 (six lanes to the right). C Total RNA extracted from mature berries at E-L 38 of nine additional dark-skinned wine grape cultivars (two lanes per cultivar). M.F.= Marechal Foch; P.N. = Pinot Noir; P.M. = Pinot Meunier; $\mathrm{GA}=$ Gamay; C.S=Cabernet Sauvignon; D.C.=De Chaunac, Mer=Merlot; Cham=Chambourcin; and B.N.= Baco Noir

collected at all three developmental stages (E-L 31, 35, and 38), and from ripe berries of additional nine darkskinned wine grape varieties were intact (Fig. 2). The integrity and concentration of total RNAs isolated from leaf and berry samples of Cabernet Franc were further analyzed by using Agilent 2100 Bioanalyzer. All RNA samples passed quality control for the purpose of RNASeq with RNA integrity number (RIN) between 6.2 and 9.9 and concentrations between 76.15-517.93 $\mathrm{ng} / \mu \mathrm{L}$ (Fig. 3 and Additional file 2: Table S2).

Total RNA preparations of all samples were tested for their suitability for downstream analyses. RNAs isolated from leaf and berry samples of Cabernet Franc at different developmental stages were tested for the presence of GLRaV-3 via RT-PCR. As expected, samples collected from vines infected with GLRaV-3 all tested positive for the virus, regardless of developmental stages. In contrast, samples from GLRaV-3-free vines all tested negative as expected (Fig. 4A). Note that the lower intensity of PCR band in lane 6 of each set of berry samples of Fig. 4A was associated with a lower viral titer present in berries of this particular vine. Total RNAs isolated from ripe berries of the additional nine dark-skinned wine grape cultivars were used as templates for RT-PCR amplification of phytoene desaturase (PDS). DNA products of PDS with the expected size were successfully generated (Fig. 4B). PDS is often used as a positive control in RT-PCR for its 'housekeeping' expression. Successful amplification of PDS indicated the presence of mRNA corresponding to PDS; hence, the robustness of RNA isolation. Total RNAs isolated from leaf and berry samples of Cabernet Franc at different developmental stages were subjected to RNASeq at Novogene, with successful results (not published). Together, these results demonstrated that total RNAs obtained using our refined protocol were of high integrity and yield and are suitable for both RT-PCR and RNA-Seq analyses.

\section{Functional enrichment analysis}

Using the TPM filtration method based on Li et al. [86], we have identified a total of 3402 and 3079 candidate reference genes in RNA-Seq datasets derived from berry and leaf samples, respectively (Additional file 3: Tables S3, S4). 2000 candidates were shared by both berry and leaf datasets and were therefore defined as the 2000 core-set reference gene candidates (Additional file 3: Table S5). These reference gene candidates were preliminarily ranked for their expressional stability based on $\mathrm{CV}$ 

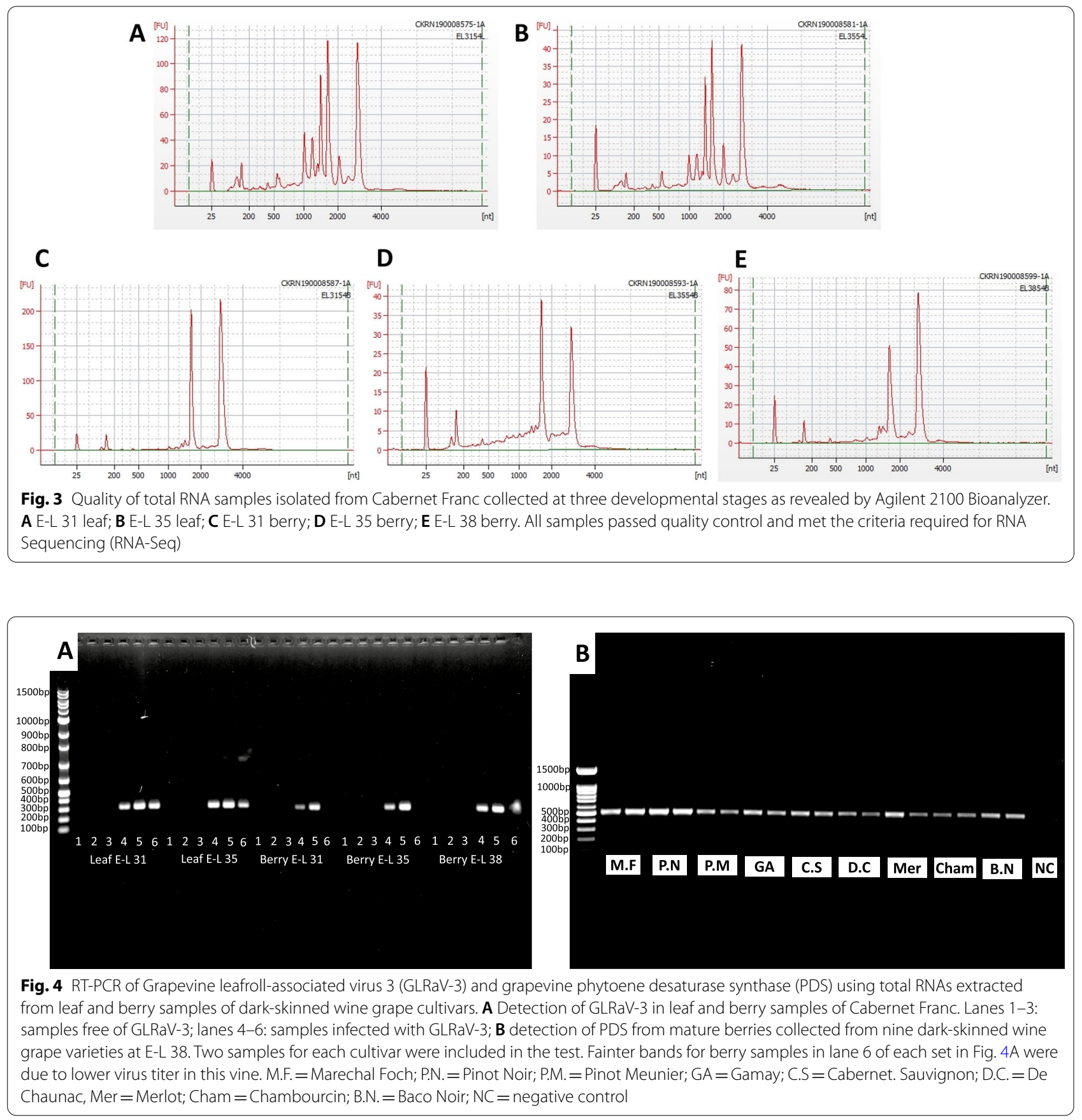

values, from the lowest (most stable) to the highest (least stable). Subsequently, GO enrichment and pathway analyses were conducted to understand their functional role in relation to host-virus interactions in different tissues at various developmental stages. $\mathrm{GO}$ analysis showed that a majority of these genes were over-represented in GO terms such as translation, nucleosome assembly, ATP hydrolysis/proton transport, tricarboxylic acid (TCA) cycle, protein folding, and ubiquitin-dependent protein catabolic process (Table 2). Results from KEGG essentially support those from GO analysis (Additional file 4: Table S6).

Seven candidate reference genes with the lowest CV values were selected from the list of the core-set reference gene candidates for further validation of their expression stability (Table 1 and Additional file 3: Table S5). These seven novel reference gene candidates are YLS8, EIF5A2 CYSP, NDUFS8, Gluc, GDT1, and EF-hand (Table 1). The 
Table 2 Significantly enriched GO terms of the 2000 core reference genes candidates of Vitis vinifera cv. Cabernet Franc

\begin{tabular}{|c|c|c|c|c|}
\hline ID code & Term & Gene number & P-value & FDR \\
\hline \multicolumn{5}{|c|}{ GO biological process } \\
\hline GO:0006412 & Translation & 95 & $1.26 \mathrm{E}-19$ & 7.17E-17 \\
\hline GO:0002181 & Cytoplasmic translation & 23 & $1.12 \mathrm{E}-11$ & $3.20 \mathrm{E}-09$ \\
\hline GO:0006334 & Nucleosome assembly & 17 & $3.62 \mathrm{E}-07$ & $6.87 \mathrm{E}-05$ \\
\hline GO:0006446 & Regulation of translational initiation & 11 & $2.66 \mathrm{E}-06$ & $3.25 \mathrm{E}-04$ \\
\hline GO:0001731 & Formation of translation preinitiation complex & 12 & $2.86 \mathrm{E}-06$ & $3.25 \mathrm{E}-04$ \\
\hline GO:0015991 & ATP hydrolysis coupled proton transport & 14 & $1.25 \mathrm{E}-05$ & 0.00118285 \\
\hline GO:0000027 & Ribosomal large subunit assembly & 13 & $4.62 \mathrm{E}-05$ & 0.0037529 \\
\hline GO:0006099 & Tricarboxylic acid cycle & 12 & $6.41 \mathrm{E}-05$ & 0.00456226 \\
\hline GO:0006457 & Protein folding & 29 & $1.04 \mathrm{E}-04$ & 0.00655506 \\
\hline GO:0043161 & Proteasome-mediated ubiquitin-dependent protein catabolic process & 30 & $1.44 \mathrm{E}-04$ & 0.00760634 \\
\hline GO:0006511 & Ubiquitin-dependent protein catabolic process & 18 & 1.47E-04 & 0.00760634 \\
\hline \multicolumn{5}{|c|}{ GO molecular function } \\
\hline GO:0003735 & Structural constituent of ribosome & 118 & $5.84 \mathrm{E}-32$ & $2.45 E-29$ \\
\hline GO:0003743 & Translation initiation factor activity & 28 & $7.11 \mathrm{E}-15$ & $1.49 \mathrm{E}-12$ \\
\hline GO:0000166 & Nucleotide binding & 52 & $1.84 \mathrm{E}-12$ & $2.57 \mathrm{E}-10$ \\
\hline GO:0004298 & Threonine-type endopeptidase activity & 14 & $1.13 \mathrm{E}-10$ & $1.18 \mathrm{E}-08$ \\
\hline GO:0003723 & RNA binding & 55 & 7.97E-08 & $6.68 \mathrm{E}-06$ \\
\hline GO:0003676 & Nucleic acid binding & 47 & $1.65 \mathrm{E}-05$ & 0.00115072 \\
\hline GO:0046961 & Proton-transporting ATPase activity, rotational mechanism & 11 & $4.34 \mathrm{E}-05$ & 0.00259685 \\
\hline GO:0003746 & Translation elongation factor activity & 10 & $1.80 \mathrm{E}-04$ & 0.00885122 \\
\hline GO:0031625 & Ubiquitin protein ligase binding & 16 & $1.90 \mathrm{E}-04$ & 0.00885122 \\
\hline \multicolumn{5}{|c|}{ GO cellular component } \\
\hline GO:0022625 & Cytosolic large ribosomal subunit & 61 & $1.44 \mathrm{E}-34$ & $2.85 E-32$ \\
\hline GO:0022627 & Cytosolic small ribosomal subunit & 31 & $1.99 \mathrm{E}-15$ & $1.96 \mathrm{E}-13$ \\
\hline GO:0033290 & Eukaryotic 485 preinitiation complex & 13 & $6.26 \mathrm{E}-08$ & $4.11 \mathrm{E}-06$ \\
\hline GO:0016282 & Eukaryotic 435 preinitiation complex & 12 & $1.23 \mathrm{E}-07$ & $6.08 \mathrm{E}-06$ \\
\hline GO:0005747 & Mitochondrial respiratory chain complex I & 11 & $2.31 \mathrm{E}-07$ & $7.58 \mathrm{E}-06$ \\
\hline GO:0005852 & Eukaryotic translation initiation factor 3 complex & 11 & $2.31 \mathrm{E}-07$ & $7.58 \mathrm{E}-06$ \\
\hline GO:0000786 & Nucleosome & 19 & $3.37 \mathrm{E}-07$ & $9.47 \mathrm{E}-06$ \\
\hline GO:0005737 & Cytoplasm & 145 & $1.73 E-06$ & 4.26E-05 \\
\hline GO:0019773 & Proteasome core complex, alpha-subunit complex & 8 & 4.01E-06 & 8.77E-05 \\
\hline GO:0005829 & Cytosol & 74 & $8.02 \mathrm{E}-05$ & 0.00157964 \\
\hline GO:0030687 & Preribosome, large subunit precursor & 12 & $5.62 \mathrm{E}-04$ & 0.00959393 \\
\hline GO:0071004 & U2-type prespliceosome & 7 & $5.84 \mathrm{E}-04$ & 0.00959393 \\
\hline
\end{tabular}

FDR false discovery rate

seven reference gene candidates were annotated using GO terms via PANTHER [90]. Briefly, YLS8, thioredoxinlike protein, was predicted to be located in the nucleus, likely serving as a component of the spliceosome [the U4/ U6 xU5 tri-small nuclear ribonucleoproteins (snRNP) complex] that functions in pre-mRNA splicing. EIF5A2 is a member of the translation initiation factor $5 \mathrm{~A}$ family and is involved in the initiation of translation. CYSP is a member of the $\mathrm{C} 1$ family of cysteine peptidases. It is associated with lysosome and is involved in protein degradation. NDUFS8, short for NADH dehydrogenase [ubiquinone] iron-sulfur protein 8 (mitochondrial), is a component of the complex I of the respiratory chain and is involved in electron transport. Gluc (endo-1,3;1,4beta-D-glucanase) has hydrolase activities. It is involved in the breakdown of glucan polymers and thus plays a role in plant cell wall loosening. GDT1, GDT1-like protein 5, is located in the Golgi apparatus and is involved in ion transport across membrane. Little is known about the function of EF-hand, though it was reported to be involved in calcium ion binding. 


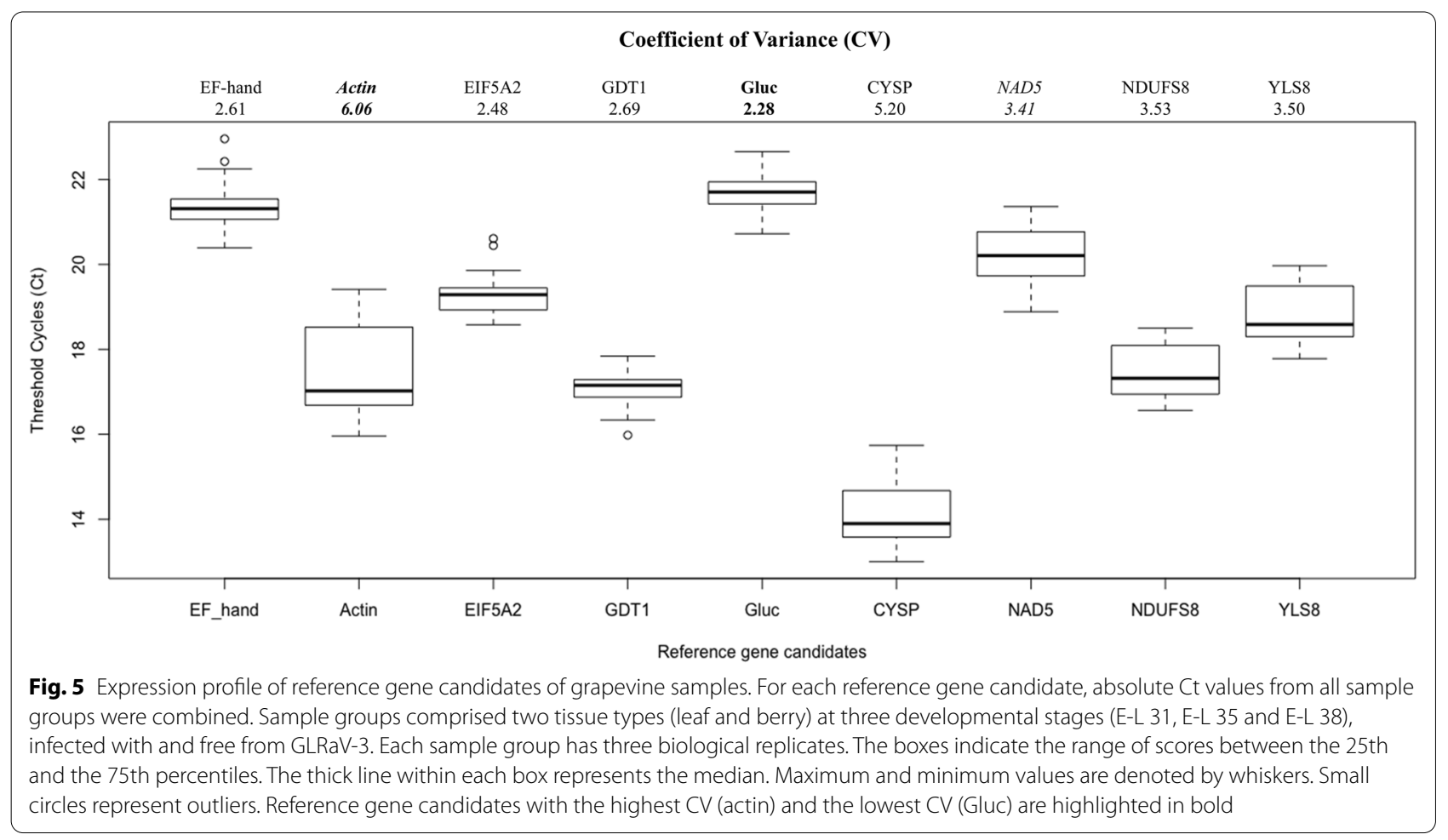

\section{Expression stability of reference gene candidates}

Absolute $\mathrm{Ct}$ values of the seven novel reference gene candidates and two conventional reference genes (actin and NAD5) from all biological samples were collected and used to plot the expression profile chart (Fig. 5). These nine candidates had mean $\mathrm{Ct}$ values ranging from 14.08 (for CYSP) to 21.67 (for Gluc) (Fig. 5), suggesting that all candidates were expressed at moderate to high levels - a desired trait of genes as internal reference for RT-qPCR quantification. The $\mathrm{CV}$ of each reference gene candidate was calculated using the absolute $\mathrm{Ct}$ values. $\mathrm{CV}$ was used to preliminarily visualize the fluctuation in expression of nine reference gene candidates across sample groups. As shown in Fig. 5, Gluc has the lowest CV at 2.28, closely followed by EIF5A2 at 2.48, EF-hand at 2.61 and GDT1 at 2.69. Interestingly, the two conventional reference genes had either the highest CV (actin at 6.06) or an intermediate CV (NAD5 at 3.41) (Fig. 5).

Three independent statistical analytic tools, GeNorm [33], NormFinder [30], and BestKeeper [88] were used to assess and rank the expressional stability of these nine candidate genes. GeNorm measures the stability of reference gene candidates by calculating gene-stability measure value $(M) . M$ is calculated based on the average pairwise variation of each candidate gene over the other candidate genes. A higher $M$ value represents a lower stability of that gene. The least stable candidate gene (having the highest $M$ value) is eliminated in a stepwise process.
Briefly, after each round of exclusion, $M$ value is recalculated for each of the remaining genes and the same pairwise exclusion process is repeated until only two genes remain. NormFinder uses ANOVA-based model to calculate stability value $(S V)$ that estimates expressional variations among the tested candidate genes. A higher $S V$ indicates a lower stability. NormFinder ranks the stability of candidate genes by taking into account both intra- and intergroup variations. Lastly, BestKeeper assesses stability of candidate genes by considering several parameters, including standard deviation $(S D)$, coefficient of variance and Pearson correlation coefficient $(r)$. Genes with the highest $r$ value and $S D<1$ are considered the most stably expressed.

Of the nine candidates tested, three novel candidate reference genes (CYSP, NDUFS8 and YLS8) identified in this study were ranked as the most stable by all three algorithms (Table 3). Stability ranking of the rest of the genes differed among tools. For example, the three least stable candidates were EF-hand, actin, and NAD5 based on geNorm; actin, EF-hand, and NAD5 by NormFinder; and NAD5, GDT1, and EF-Hand by BestKeeper (Table 3). It is important to note that both actin and NAD5, two conventional reference genes commonly reported in past gene expression literature [4, 91-94], ranked among the least stable by all three algorithms, with the exception that actin was ranked in the middle by BestKeeper. 
Table 3 Stability rankings of grapevine candidate reference genes across different sample groups (two tissue types, three developmental stages, infected with or free from GLRaV-3) according to geNorm, NormFinder and BestKeeper

\begin{tabular}{|c|c|c|c|c|c|c|c|}
\hline \multirow[t]{3}{*}{ Rank } & \multicolumn{7}{|l|}{ Program } \\
\hline & \multicolumn{2}{|l|}{ geNorm } & \multicolumn{2}{|c|}{ NormFinder } & \multicolumn{3}{|c|}{ BestKeeper } \\
\hline & Gene & $M$ & Gene & SV & Gene & SD & $r$ \\
\hline 1 & $\mathrm{CYSP}^{1}$ & 0.277983 & CYSP $^{1}$ & 0.09 & $\mathrm{CYSP}^{1}$ & 0.6 & 0.951 \\
\hline 2 & NDUFS8 $^{1}$ & 0.277983 & NDUFS8 $^{1}$ & 0.14 & NDUFS8 $^{1}$ & 0.53 & 0.941 \\
\hline 3 & YLS8 $^{1}$ & 0.401338 & YLS8 $^{1}$ & 0.17 & YLS8 $^{1}$ & 0.58 & 0.879 \\
\hline 4 & Gluc & 0.514505 & EIF5A2 & 0.35 & $\underline{\text { Actin }}^{2}$ & 0.96 & 0.879 \\
\hline 5 & EIF5A2 & 0.535890 & Gluc & 0.42 & Gluc & 0.38 & 0.726 \\
\hline 6 & GDT1 & 0.563192 & GDT1 & 0.59 & EIF5A2 & 0.35 & 0.641 \\
\hline 7 & EF-hand & 0.656230 & $\underline{\text { Actin }}^{2}$ & 0.70 & $\underline{N A D 5}^{2}$ & 0.57 & 0.562 \\
\hline 8 & $\underline{\text { Actin }}^{2}$ & 0.872071 & EF-hand & 0.76 & GDT1 & 0.35 & 0.51 \\
\hline 9 & $\underline{N A D}^{2} \underline{2}$ & 3.809479 & $\underline{N A D 5}^{2}$ & 3.78 & EF-hand & 0.4 & 0.335 \\
\hline
\end{tabular}

${ }^{1}$ The three most stable reference gene candidates are bolded. ${ }^{2} \mathrm{~T} w o$ conventionally used reference genes were underscored

$S V$ stability value, $S D$ standard deviation, $r$ Pearson coefficient of correlation

\section{Comparative analysis of CYSP, actin and NAD5 as reference genes for normalization of UFGT}

Anthocyanidin 3-O-glucosyltransferase (UFGT) is a key enzyme involved in the biosynthesis of anthocyanins. Two independent studies have reported that UFGT expression was up-regulated in symptomatic leaves but down-regulated in mature berries of dark-skinned grapevine cultivars in response to $\mathrm{GLRaV}-3$ infection $[4,5]$. We hypothesized that the use of improper (i.e., less stable) reference genes would lead to incorrect conclusions in RT-qPCR gene expression studies. We performed RTqPCR analysis on the expression of UFGT in both leaf and berry samples in the context of GLRaV-3 infection (GLRaV-3-infected vs. GLRasV-3 free). For the purpose of comparison, the best-ranking reference gene (CYSP) identified in this study and two of the conventional reference genes previously used by other researchers, actin and NAD5, were used to individually normalize UFGT expressional data. As stated earlier, actin and NAD5 were ranked among the least stable genes based on analyses using three different algorithms.
First, we wanted to see if the use of less stable reference genes would lead to bias in calling of the significance of UFGT expressional change in response to GLRaV-3 infection. Raw UFGT RT-qPCR expression data was normalized individually against CYSP, actin, and NAD5, generating three relative expression datasets: CYSP-dataset, actin-dataset, and NAD5-dataset. For each dataset, UFGT relative expressions of GLRaV-3-infected samples were compared to GLRaV-3-free samples using oneway ANOVA. Leaf samples at E-L 35 and berry samples at E-L 38 were chosen for this analysis. In leaf samples, UFGT expression was shown to be significantly upregulated in response to GLRaV-3 infection in both the CYSP-dataset $(\mathrm{P}<0.01)$ and the NAD5-dataset $(\mathrm{P}<0.001)$ (Fig. 6A). Expression of UFGT in berry samples was significantly down-regulated in response to GLRaV-3 infection (CYSP-dataset: $\mathrm{P}<0.05$ and NAD5-dataset: $\mathrm{P}<0.05$ ) (Fig. 6B). However, contrary to what was reported in the literature $[4,5]$, no significant difference was found in UFGT expression between GLRaV-3-infected and GLRaV-3-free samples when the data was normalized to actin $(\mathrm{P}>0.05)$ (Fig. 6A, B).

\footnotetext{
(See figure on next page.)

Fig. 6 UFGT relative expressions as normalized against three reference genes (CYSP, actin, and NAD5), in GLRaV-3-infected (orange bars) as compared to GLRaV-3-free (grey bars) E-L 35 leaf (A) and E-L 38 berry (B) of Cabernet Franc. Statistical significance of UFGT expressional change in GLRaV-3-infected vs. GLRaV-3-free samples was evaluated using one-way ANOVA. A In Cabernet Franc leaf at E-L 35, dataset normalized to CYSP (left, ${ }^{* *} \mathrm{P}=0.00768$ ) and to NAD5 (right, ${ }^{* *}{ }^{*} \mathrm{P}=0.00079$ ) showed that UFGT expression in GLRaV-3-infected leaf was significantly different from that in GLRaV-3-free leaf. Data set normalized to actin (middle) showed no significant difference between GLRaV-3-infected leaf and GLRaV-3-free leaf (ns, $P=0.23146$ ). $\mathbf{B}$ In berry at $E-L 38$, data sets normalized to CYSP (left, ${ }^{*} P=0.02235$ ) and to NAD5 (right, ${ }^{*} P=0.03925$ ) showed that UFGT expression was significantly different in GLRaV-3-infected samples compared to GLRaV-3-free samples. However, data set normalized to actin (middle) revealed no significant difference in UFGT expression due to GLRaV-3-infection ( $n S, P=0.77989$ ). UFGT relative expressions were generated by normalizing raw quantification data against each of the three reference genes (CYSP, actin, NAD5). Relative expression values are mean, $\pm S D$ (error bars), $n=3$. ns: not significant $(P>0.05)$; ${ }^{*}$ significant $(0.01<P<0.05)$; ${ }^{* *}$ significant $(0.001<P<0.01)$; ${ }^{* *}$ significant $(P<0.001)$
} 


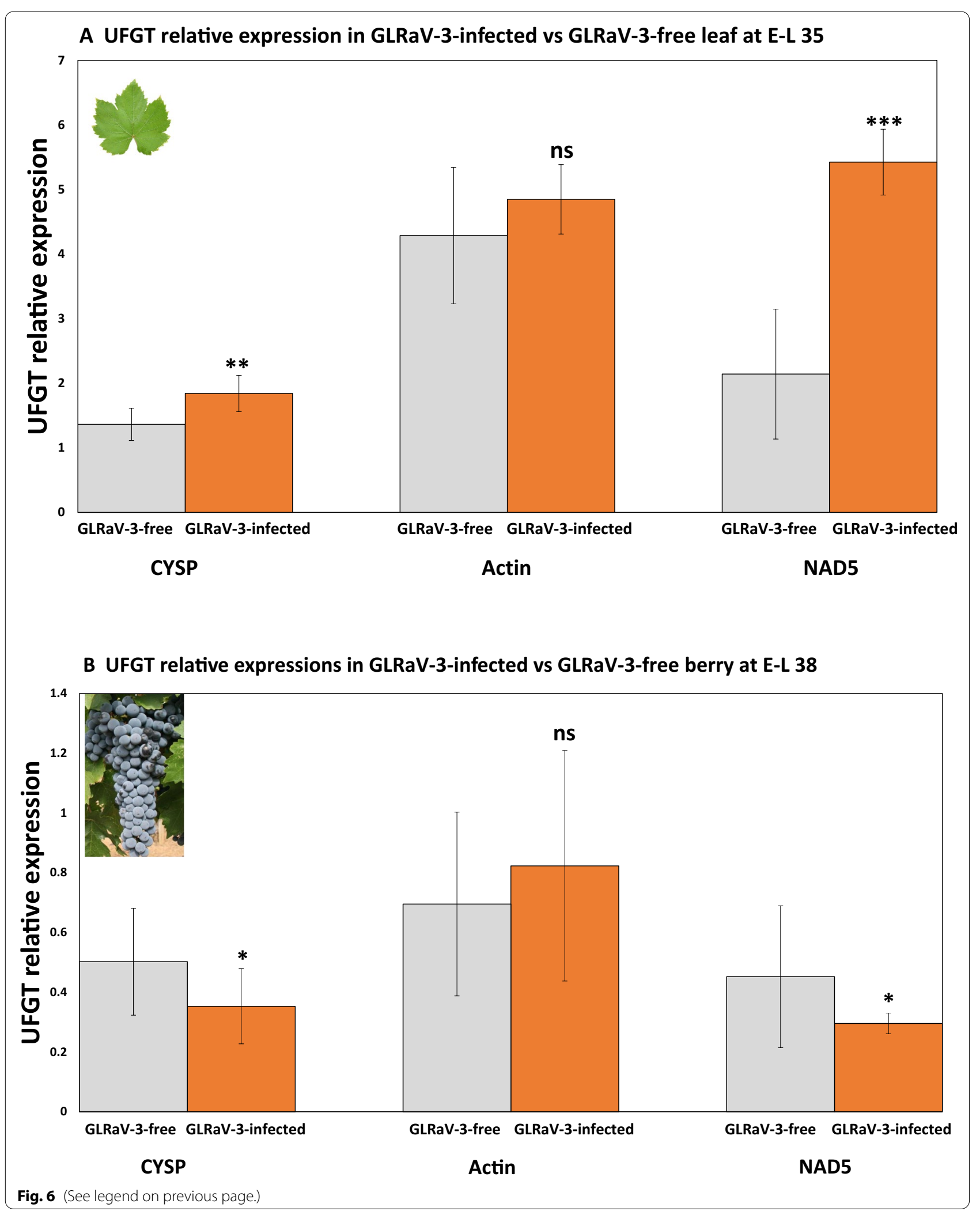


Since UFGT was determined as significantly differentially regulated in both datasets normalized to CYSP and to NAD5 (Fig. 6A, B), we further tested if normalization using NAD5 would lead to bias in the calculation of fold-change (FC) values. Here, FC values were calculated using the Pfaffl method [95]. We found that in GLRaV3-infected leaf at E-L 35, UFGT was up-regulated by 1.44-folds when CYSP was used to normalize the data. In contrast, it was substantially up-regulated (at 2.50folds) when NAD5 dataset was used (Fig. 7). One-way ANOVA analysis revealed that the FC value based on the NAD5-dataset was significantly different from that based on the CYSP-dataset in leaf samples $(P<0.001)$ (Fig. 7, left panel). Therefore, bias was found in calculating the degree of gene expressional change ( $F C$ values) when a less stable reference gene (i.e., NAD5) was used as compared to the most stable reference gene (i.e., CYSP). In berry samples infected with GLRaV-3, UFGT was down-regulated by -1.33 -folds when using CYSP as normalization factor, and by -1.62 -folds when using NAD5 as normalization factor (Fig. 7, right panel). The two FC values were not statistically different from each other $(\mathrm{P}>0.05)$. Based on these results, we conclude that the selection of stable reference genes is essential for the quantification of gene expression studies. As compared to the more stable novel reference gene (CYSP), less stable reference genes such as actin and NAD5 would necessarily lead to bias in the calling of both the significance and the degree of fold-change of grapevine gene expression analysis through RT-qPCR.

\section{Discussion}

The refined protocol is highly effective in isolating quality RNA from berries of dark-fruited wine grapes

Our lab had previously tackled challenges in RNA isolation from old grapevine leaves with GLRD symptoms [81]. We further refined the protocol by altering parameters involving berry mass and 2-ME concentration at the lysis step in order to overcome challenges in RNA isolation of ripening and mature dark-skinned wine grapes that arose due to increased polyphenolics, polysaccharides, waster, RNases contents and decreased RNA concentration. The optimized RNA isolation protocol we report here differs from previous procedures for RNA isolation from berries by eliminating the need for organic chemicals (phenol and chloroform), significantly
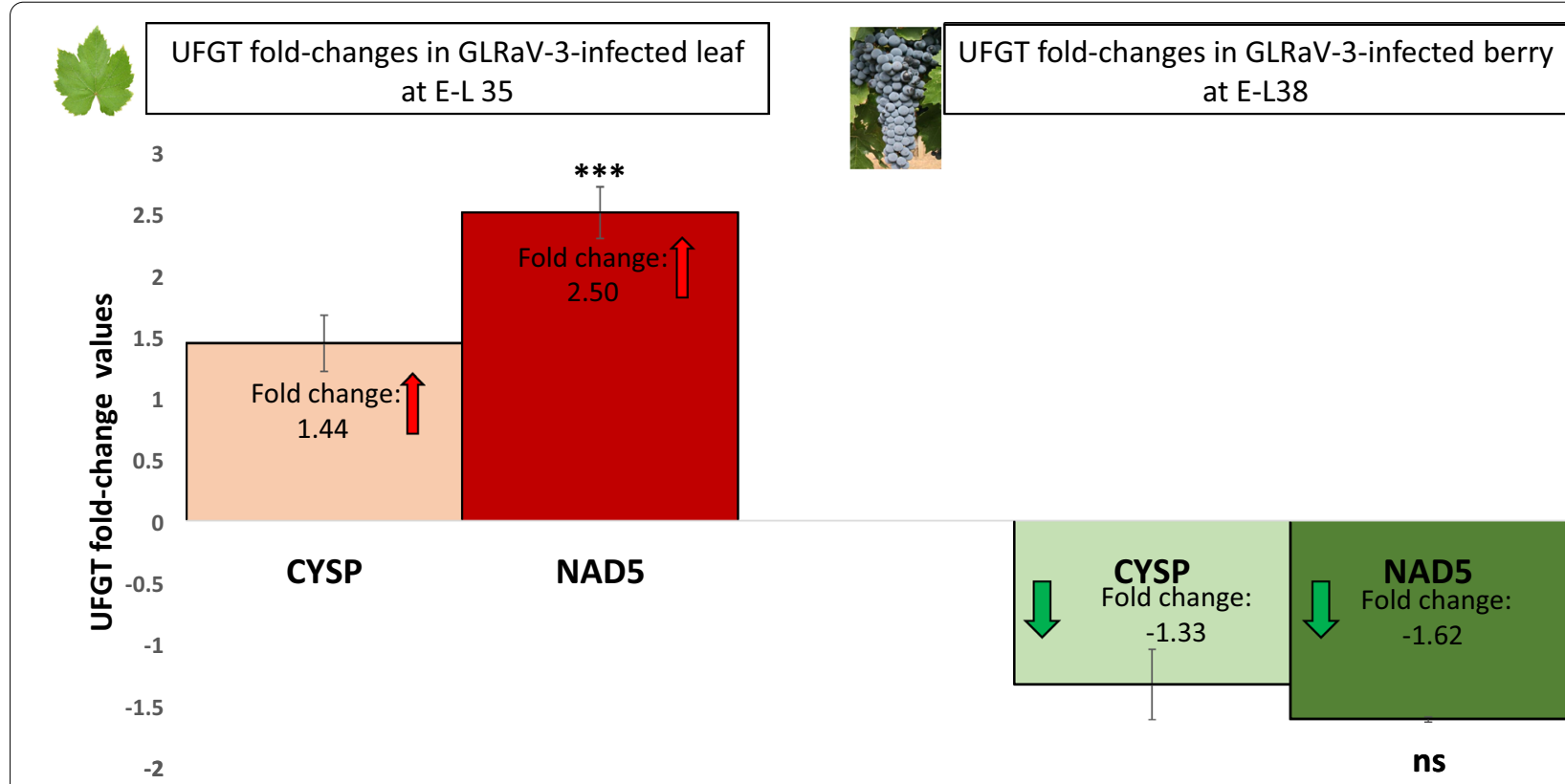

Fig. 7 Difference in UFGT fold-change (FC) called in datasets normalized to CYSP and to NAD5 in GLRaV-3-infected leaf at E-L 35 (left), and GLRaV-3-infected berry at E-L 38 (right). Statistical difference between the FC values called in CYSP-dataset and in NAD5-dataset was analyzed using one-way ANOVA. In GLRaV-3-infected leaf (left), UFGT was up-regulated by 1.44-folds when dataset was normalized against CYSP and by 2.50-folds when normalized against NAD5. The FC value from NAD5-dataset was significantly different from that from CYSP-dataset (***P=0). In GLRaV-3-infected berry at E-L 38 (right), UFGT was down-regulated by -1.33 -folds when dataset was normalized against CYSP and by - 1.62-folds when dataset was normalized against NAD5. No significant difference was found between the two FC values (ns, P = 0.23303). UFGT fold change values were calculated using Pfaffl method [95]. FC values are mean, \pm SD (error bars), $n=3$. Positive FC values represent up-regulation of gene (in response to GLRaV-3 infection) and are depicted by red arrows. Negative FC values represent down-regulation (in response to GLRaV-3 infection) and are depicted by green arrows. ns: not significant $(P>0.05)$; ${ }^{*}$ significant $(0.01<P<0.05)$; ${ }^{* *}$ significant $(0.001<P<0.01)$; ${ }^{* * *}$ significant $(P<0.001)$ 
shortened assay time (around two hours per batch of RNA isolation) and larger sample size (around twentyfour sample per batch of RNA isolation). We demonstrated that this protocol was suitable for total RNA extraction from leaf and whole berries from a wide range of wine grapes at different phenological stages, including those from vines with viral symptoms. Lastly, we further demonstrated that the resulting RNA preps were suitable for several downstream applications such as RT-PCR, RT-qPCR and RNA-Seq.

\section{Bioinformatics analyses of RNA-Seq dataset enabled identification of a set of stably expressed genes involved in several biological pathways}

Using an established bioinformatics pipeline [86], we have identified 2000 genes from Cabernet Franc as the core-set candidate reference genes. Functional enrichment analysis revealed that these candidate genes were largely over-represented in biological activities associated with translation and transcription, including ribosomal assembly, regulation of translation initiation, nucleosome assembly, and nucleotide binding. In addition, some of them were involved in TCA cycle, oxidative phosphorylation, and proteasome-associated protein catabolism (Table 2). Our results were in line with recent studies on wheat [57], rice [96], tomato infected with Xanthomonas campestris [45], poplar infected with Botryosphaeria dothidea [47], and other organisms such as humans with non-melanoma skin cancers [97], solitary sea squirt [98], blood trematodes [62], and scallop [86]. These studies have all identified their novel reference gene candidates to be over-represented in protein synthesis and protein turnover (ubiquitination/proteolysis). Activities associated with transcription, translation, and protein turnover are among the most fundamental cellular processes in all types of organisms. Novel reference gene candidates constantly found as over-represented in these cellular activities suggest that these functions may serve as better pools for reference gene selection than the traditionally touted 'housekeeping' functions, such as cell structure (actin and tubulin), glycolysis (GAPDH), among others. In fact, it has become increasingly clear that these 'housekeeping' genes are heavily regulated under various conditions [35, 99-101].

Some of the core-set reference gene candidates identified in our study were also over-represented in respiration process including oxidative phosphorylation and TCA cycle (Table 2 and Additional file 4: Table S6). TCA cycle and oxidative phosphorylation occur in mitochondria and are fundamentally important processes involved in carbohydrate metabolism and ATP production. GLRaV-3 was reported to form viral replication complexes in association with mitochondrial membrane of infected host cells [102-104]. It is hypothesized that GLRaV-3 infections cause damages to mitochondria; and that genes associated with mitochondrial processes would be differentially regulated in GLRaV-3-infected grapevines [70]. Interestingly, results from our study and those reported by others $[44,57,86,97]$ have identified some of the genes involved in respiration as being stably expressed. It is important to note that regulation of gene expression involves a complex network. A subset of genes stably expressed in a biological process cannot be used as evidence to suggest that the said biological process was non-differentially regulated under an experimental condition. As a response to GLRaV-3 infection, it is possible that other genes involved in respirational process, not identified among our 2000 core reference genes candidates, were differentially regulated, consequently, leading to the differential regulation of the general mitochondrial processes. This supposition could be tested by performing proteomic and metabolomic analyses on grapevine infected with GLRaV-3 to examine the regulation of mitochondrial processes at the post-transcriptional level.

\section{Novel reference genes outperformed traditional reference genes in transcripts quantification}

NAD5 and actin were two of the conventional reference genes used in gene expression studies involving RT-qPCR $[4,91-94]$. They were regarded as the most suitable reference genes in the context of GLRaV-3 infection in grapevine leaf [4]. By using three analytical tools (geNorm, NormFinder, and BestKeeper) commonly used for ranking of gene stability, we compared the stability of seven novel reference gene candidates that we have identified in this study with that of NAD5 and actin across two tissue types (leaf and berry), three developmental stages (E-L 31, E-L 35 and E-L 38), and status of GLRaV-3 infection. Results from geNorm, NormFinder and BestKeeper have generated identical rankings on the three most stable reference genes - CYSP, NDUFS8, and YSL8. In stark contrast, actin and NAD5 were ranked among the least stable, suggesting their high levels of variation in expression and hence unsuitability as normalization factors for the quantification of gene expression in grapevine.

In RT-qPCR assays, many of the conventionally used reference genes were consistently found to exhibit high expressional variation in various plant species and other organisms [38, 45-47, 57-60, 62, 63]. For example, a recent study by Upadhyay et al. [55] found that actin was the least stable gene in grapevine upon treatment with GA3 application. Gamm et al. [64] and González-Agüero et al. [66], using data from microarray and RNA-Seq respectively, have identified novel reference gene candidates in a dark-skinned grapevine cultivar infected with P. viticola and B. cinerea [64] and genes stably expressed 
in table grapes at different phenological stages and under abiotic stress [66]. They concluded that all three traditionally used reference genes (18S rRNA, EF1-alpha and UBA10) had higher variation in gene expression when compared to the novel reference gene candidates they identified [64, 66]. Our findings were consistent with those from these earlier studies-actin and NAD5 were amongst the most unstable when compared to the seven novel reference gene candidates identified in the present study.

The most characteristic symptoms of GLRaV-3-infection in dark-skinned grapevine cultivars are the downward curling of leaf margins and red to purple pigmentation of interveinal regions in leaves [70]. The discoloration of GLRaV-3-infected leaves is associated with increased biosynthesis of anthocyanins, likely resulting from the up-regulation of UFGT gene [4]. In this study, we have revealed that the expression of UFGT was significantly up-regulated in leaf tissue at E-L 35 but significantly down-regulated in berry at E-L 38 of GLRaV3-infected Cabernet Franc, when either CYSP or NAD5 was used as a reference gene (Fig. 5A, B). This result was in agreement with two independent studies reported earlier $[4,5]$. However, when actin was used as the reference gene, no significant difference was found in UFGT expression between GLRaV-3-infected and GLRaV-3-free samples in either leaf or berry (Fig. 5A, B). Actin has been routinely used by many research groups as a reference gene in gene expression studies $[40,41,105-113]$. Our results raised questions on the validity of conclusions of earlier reports where actin was used as a reference gene in analysis involving grapevine and viral infections. The use of actin for such purposes would lead to false identification of statistical significance of a differential regulation, resulting in misinterpretation of data and wrong conclusions to be reached.

Results of analyses using geNorm, NormFinder and BestKeeper were consistent with one another on identifying NAD5, one of the conventionally used reference genes, as less stable than CYSP, the novel reference gene candidate identified in this study with top stability ranking. When we compared the difference in RT-qPCR results between datasets normalized against NAD5 and CYSP, we found that NAD5 led to bias in calling FC values. FC values reveal both the direction and degree of gene expressional change under an experimental condition. The dataset normalized to NAD5 called UFGT to be up-regulated by 2.50 -folds, whereas CYSP-adjusted dataset called UFGT up-regulation by 1.44 -folds. These two FC values were drastically different as judged by statistical analysis (Fig. 7). Bias in FC calling not only impact the interpretation of data in terms of the degree of regulation and biological relevance of a differentially expressed gene, but may also skew the decision of researchers as to which gene to select as a priority for further studies. Therefore, skewed results in significance test as well as $F C$ calling based on the use of improper reference genes, such as actin and NAD5, further emphasize the importance of reference gene selection for use in RT-qPCR quantification studies.

Out results were in agreement with previous studies that novel reference genes identified via genome-wide screening outperformed the conventional reference genes $[38,45-47,57-60,62-64,66]$. This opens discussions for future studies on the potential bias caused by preferentially picking reference gene candidates solely based on those typically used as reported in the literature, without actual evidence to support their suitability as reference genes under the experimental condition in question. In accordance with the recommendation that at least three reference genes should be used for robust normalization of RT-qPCR data [33, 114], we propose the use of CYSP, NDUFS8 and YSL8, for future studies involving the effects of GLRaV-3 infection on grapevine gene expression through RT-qPCR.

\section{Conclusions}

Grape berries are essential to investigations related to fruit chemistry and wine quality. Various molecular assays are employed to assess the expression of genes related to fruit and wine quality and the impact of abiotic and biotic stress factors such as infection with viruses. A key to the success of such assays is an effective protocol that allows sufficient amounts of quality RNA to be obtained from berries collected from veraison and later stages. In this work, we established an optimized protocol through modifications of a total RNA isolation system from Sigma. We have shown that this refined protocol was effective in RNA isolation from older berries of an array of dark-skinned wine grape cultivars, including $V$. vinifera wine grapes and French-American hybrids, resulting in higher yield and integrity. We have further shown that the resulting RNA preps were suitable for downstream applications including amplification of viral RNAs and grapevine genes via RT-PCR, RT-qPCR, and RNA-Seq. We hope that the RNA isolation system we have refined in this work will have utilities in broad research involving grapevine molecular biology, developmental biology, and virus-host interactions.

Using RNA-Seq data derived from leaf and berry of Cabernet Franc at three developmental stages, we have identified three novel candidate reference genes for RT-qPCR-based gene expression studies of grapevine: CYSP, NDUFS8, and YSL8. We have shown that these novel reference genes were superior over actin and NAD5, two of the conventional reference genes previously used 
in studies involving grapevine and GLRaV-3. Furthermore, we have demonstrated that the choice of improper reference genes for normalization of RT-qPCR data would lead to erroneous conclusions. We anticipate that the three novel reference genes will be useful for studies involving grapevine infections by other viruses involved in the grapevine leafroll disease complex and perhaps many other grapevine viruses. It will be interesting to see if these new reference genes would prove stable under other adverse conditions such as infections by fungal and bacterial pathogens, or insect attack. Naturally, this needs to be tested via experimentation.

\section{Supplementary Information}

The online version contains supplementary material available at https://doi. org/10.1186/s13007-021-00808-4.

Additional file 1: Table S1. Total RNA purity and concentration assessment of all samples examined in this study using NanoDrop 1000.

Additional file 2: Table S2. Integrity (RIN) and concentration of total RNA from leaf and berry samples of Cabernet Franc as analyzed by Agilent 2100 Bioanalyzer.

Additional file 3: Table S3. Candidate reference genes identified in RNA-Seq dataset of leaf samples as ordered by CV values of leaf. Table S4. Candidate reference genes identified in RNA-Seq dataset of berry samples as ordered by CV values of berry. Table S5. 2000 core candidate reference genes shared by leaf and berry RNA-Seq datasets, ranked by mean CV of CV_leaf and CV_berry.

Additional file 4: Table S6. Enriched KEGG pathways of 2000 core candidate reference genes.

\section{Acknowledgements}

We thank the University of Guelph for providing International Graduate Tuition Scholarships to Yashu Song. We thank Vieni Estate Inc. for providing grapevine samples. Without their generous and continued support, this research would not have been possible. We thank Patrick Lameront for reviewing the manuscript.

\section{Authors' contributions}

Conceptualization: BM and YS; methodology, software and investigations: YS; writing —original draft: YS; writing — review and editing: BM; project administration, $\mathrm{BM}$ and $\mathrm{RH}$; funding and resources: $\mathrm{BM}$ and $\mathrm{RH}$. All authors have agreed to the submission of the manuscript for publication. All authors read and approved the final manuscript.

\section{Funding}

This research is funded in part by the Natural Science and Engineering Research Council (NSERC) of Canada (Grant No. RGPIN-2020-04718). This research is partially supported by the Canadian Food Inspection Agency FAP program.

\section{Availability of data and materials}

All data generated or analysed during this study are included in this article and its Additional files.

\section{Declarations}

Ethics approval and consent to participate

Not applicable.

\section{Consent for publication}

All authors consent on the submission of this paper for publication in Plant Methods.

\section{Competing interests}

The authors declare that they have no competing interest, financial or personal, that would influence the work reported in this paper.

\section{Author details}

${ }^{1}$ Department of Molecular and Cellular Biology, University of Guelph, 50 Stone Road, Guelph, ON N1G2W1, Canada. ${ }^{2}$ Department of Integrative Biology, University of Guelph, 50 Stone Road, Guelph, ON N1G2W1, Canada.

Received: 7 August 2021 Accepted: 10 October 2021

Published online: 28 October 2021

\section{References}

1. OIV. Statistical report on world vitiviniculture. 2019:1-23. https://www oiv.int/public/medias/6782/oiv-2019-statistical-report-on-world-vitiv iniculture.pdf. Accessed 27 Nov 2020.

2. Shabanian M, Xiao H, Meng B. Seasonal dynamics and tissue distribution of two major viruses associated with grapevine leafroll under cool climate condition. Eur J Plant Pathol. 2020;158:1017-31. https://doi.org/ 10.1007/s10658-020-02137-z.

3. Xiao H, Li C, Al Rwahnih M, Dolja V, Meng B. Metagenomic analysis of riesling grapevine reveals a complex virome including two new and divergent variants of grapevine leafroll-associated virus 3. Plant Dis. 2019;103:1275-85. https://doi.org/10.1094/PDIS-09-18-1503-RE.

4. Gutha LR, Casassa LF, Harbertson JF, Naidu RA. Modulation of flavonoid biosynthetic pathway genes and anthocyanins due to virus infection in grapevine (Vitis vinifera L.) leaves. BMC Plant Biol. 2010;10:187. https:// doi.org/10.1186/1471-2229-10-187.

5. Vega A, Gutiérrez RA, Peña-Neira A, Cramer GR, Arce-Johnson P. Compatible GLRaV-3 viral infections affect berry ripening decreasing sugar accumulation and anthocyanin biosynthesis in Vitis vinifera. Plant Mol Biol. 2011;77:261-74. https://doi.org/10.1007/s11103-011-9807-8.

6. Giribaldi M, Purrotti M, Pacifico D, Santini D, Mannini F, Caciagli P, et al. A multidisciplinary study on the effects of phloem-limited viruses on the agronomical performance and berry quality of Vitis vinifera cv. Nebbiolo. J Proteom. 2011;75:306-15. https://doi.org/10.1016/j.jprot.2011. 08.006.

7. Li M, Zhang J, Feng M, Wang X, Luo C, Wang Q, et al. Characterization of silencing suppressor p24 of Grapevine leafroll-associated virus 2. Mol Plant Pathol. 2018;19:355-68. https://doi.org/10.1111/mpp.12525.

8. Poojari S, Alabi OJ, Naidu RA. Molecular characterization and impacts of a strain of grapevine leafroll-associated virus 2 causing asymptomatic infection in a wine grape cultivar. Virol J. 2013;10:324. https://doi.org/10. 1186/1743-422X-10-324.

9. Xiao H, Shabanian M, Moore C, Li C, Meng B. Survey for major viruses in commercial Vitis vinifera wine grapes in Ontario. Virol J. 2018;15:127. https://doi.org/10.1186/s12985-018-1036-1.

10. Cui Z-H, Bi W-L, Hao X-Y, Li P-M, Duan Y, Walker MA, et al. Drought stress enhances up-regulation of anthocyanin biosynthesis in grapevine leafroll-associated virus 3-infected in vitro grapevine (Vitis vinifera) leaves. Plant Dis. 2017;101:1606-15. https://doi.org/10.1094/ PDIS-01-17-0104-RE.

11. El Aou-ouad H, Bota J, Obata T, Montero R, Fernie AR, Medrano H, et al. Combined drought and virus infection trigger aspects of respiratory metabolism related to grapevine physiological responses. J Plant Physiol. 2018;231:19-30. https://doi.org/10.1016/j.jplph.2018.08.009.

12. Weng K, Li Z-Q, Liu R-Q, Wang L, Wang Y-J, Xu Y. Transcriptome of Erysiphe necator-infected Vitis pseudoreticulata leaves provides insight into grapevine resistance to powdery mildew. Hortic Res. 2014;1:14049. https://doi.org/10.1038/hortres.2014.49.

13. Espinoza C, Vega A, Medina C, Schlauch K, Cramer G, Arce-Johnson P. Gene expression associated with compatible viral diseases in grapevine cultivars. Funct Integr Genom. 2007;7:95-110. https://doi.org/10.1007/ s10142-006-0031-6. 
14. Blanco-Ulate B, Hopfer H, Figueroa-Balderas R, Ye Z, Rivero RM, Albacete $A$, et al. Red blotch disease alters grape berry development and metabolism by interfering with the transcriptional and hormonal regulation of ripening. J Exp Bot. 2017;68:1225-38. https://doi.org/10.1093/ jxb/erw506.

15. Reid KE, Olsson N, Schlosser J, Peng F, Lund ST. An optimized grapevine RNA isolation procedure and statistical determination of reference genes for real-time RT-PCR during berry development. BMC Plant Biol. 2006;6:27. https://doi.org/10.1186/1471-2229-6-27.

16. Davis AR, Levi A, Kim S, King SR, Hernandez A. RNA extraction method from fruit tissue high in water and sugar. HortScience. 2006;41:1292-4.

17. Sánchez C, Villacreses J, Blanc N, Espinoza L, Martinez C, Pastor G, et al. High quality RNA extraction from Maqui berry for its application in next-generation sequencing. Springerplus. 2016;5:1243. https://doi.org/ 10.1186/s40064-016-2906-x.

18. Gudenschwager O, González-Agüero M, Defilippi BG. A general method for high-quality RNA isolation from metabolite-rich fruits. S Afr J Bot. 2012;83:186-92. https://doi.org/10.1016/j.sajb.2012.08.004.

19. Fort F, Hayoun L, Valls J, Canals JM, Arola L, Zamora F. A new and simple method for rapid extraction and isolation of high-quality RNA from grape (Vitis vinifera) berries. J Sci Food Agric. 2008;88:179-84. https:// doi.org/10.1002/jsfa.3066.

20. Rienth M, Torregrosa L, Ardisson M, De Marchi R, Romieu C. Versatile and efficient RNA extraction protocol for grapevine berry tissue, suited for next generation RNA sequencing. Aust J Grape Wine Res. 2014;20:247-54. https://doi.org/10.1111/ajgw.12077.

21. Japelaghi RH, Haddad R, Garoosi G-A. Rapid and efficient isolation of high quality nucleic acids from plant tissues rich in polyphenols and polysaccharides. Mol Biotechnol. 2011;49:129-37. https://doi.org/10. 1007/s12033-011-9384-8.

22. landolino AB, Goes da Silva F, Lim H, Choi H, Williams LE, Cook DR. High-quality RNA, CDNA, and derived EST libraries from grapevine (Vitis vinifera L.). Plant Mol Biol Rep. 2004;22:269-78. https://doi.org/10.1007/ BF02773137.

23. Mami S, Shiratake K. Total RNA extraction from grape berry skin for quantitative reverse transcription PCR and microarray analysis. Bioprotocol. 2016. https://doi.org/10.21769/BioProtoc.1777.

24. Huggett J, Dheda K, Bustin S, Zumla A. Real-time RT-PCR normalisation; strategies and considerations. Genes Immun. 2005;6:279-84. https:// doi.org/10.1038/sj.gene.6364190.

25. Mintz-Oron S, Mandel T, Rogachev I, Feldberg L, Lotan O, Yativ M, et al. Gene expression and metabolism in tomato fruit surface tissues. Plant Physiol. 2008;147:823-51. https://doi.org/10.1104/pp.108.116004.

26. Huang W, Xian Z, Kang X, Tang N, Li Z. Genome-wide identification, phylogeny and expression analysis of GRAS gene family in tomato. BMC Plant Biol. 2015;15:209. https://doi.org/10.1186/s12870-015-0590-6.

27. Mekawy AMM, Assaha DVM, Yahagi H, Tada Y, Ueda A, Saneoka H. Growth, physiological adaptation, and gene expression analysis of two Egyptian rice cultivars under salt stress. Plant Physiol Biochem. 2015;87:17-25. https://doi.org/10.1016/j.plaphy.2014.12.007.

28. Shankar A, Singh A, Kanwar P, Srivastava AK, Pandey A, Suprasanna P, et al. Gene expression analysis of rice seedling under potassium deprivation reveals major changes in metabolism and signaling components. PLoS ONE. 2013;8: e70321. https://doi.org/10.1371/journal.pone. 0070321.

29. Takeuchi M, Watanabe A, Tamura M, Tsutsumi Y. The gene expression analysis of Arabidopsis thaliana ABC transporters by real-time PCR for screening monolignol-transporter candidates. J Wood Sci. 2018;64:47784. https://doi.org/10.1007/s10086-018-1733-9.

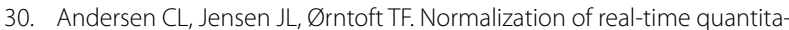
tive reverse transcription-PCR data: a model-based variance estimation approach to identify genes suited for normalization, applied to bladder and colon cancer data sets. Cancer Res. 2004;64:5245-50. https://doi. org/10.1158/0008-5472.CAN-04-0496.

31. Schmidt GW, Delaney SK. Stable internal reference genes for normalization of real-time RT-PCR in tobacco (Nicotiana tabacum) during development and abiotic stress. Mol Genet Genom. 2010;283:233-41. https://doi.org/10.1007/s00438-010-0511-1.

32. Expósito-Rodríguez M, Borges AA, Borges-Pérez A, Pérez JA. Selection of internal control genes for quantitative real-time RT-PCR studies during tomato development process. BMC Plant Biol. 2008;8:131. https://doi. org/10.1186/1471-2229-8-131.

33. Vandesompele J, De Preter K, Pattyn F, Poppe B, Van Roy N, De Paepe A, et al. Accurate normalization of real-time quantitative RT-PCR data by geometric averaging of multiple internal control genes. Genome Biol. 2002. https://doi.org/10.1186/gb-2002-3-7-research0034.

34. Chapman JR, Waldenström J. With reference to reference genes: a systematic review of endogenous controls in gene expression studies. PLOS ONE. 2015;10: e0141853. https://doi.org/10.1371/journal.pone. 0141853.

35. Nestorov J, Matić G, Elaković I, Tanić N. Gene expression studies: how to obtain accurate and reliable data by quantitative real-time RT PCR. J Med Biochem. 2013;32:325-38. https://doi.org/10.2478/ jomb-2014-0001.

36. VanGuilder HD, Vrana KE, Freeman WM. Twenty-five years of quantitative PCR for gene expression analysis. Biotechniques. 2008;44:619-26. https://doi.org/10.2144/000112776.

37. Borges AF, Fonseca C, Ferreira RB, Lourenço AM, Monteiro S. Reference gene validation for quantitative RT-PCR during biotic and abiotic stresses in Vitis vinifera. PLoS ONE. 2014;9: e111399. https://doi.org/10. 1371/journal.pone.0111399.

38. Czechowski T, Stitt M, Altmann T, Udvardi MK, Scheible W-R. Genomewide identification and testing of superior reference genes for transcript normalization in Arabidopsis. Plant Physiol. 2005;139:5-17. https://doi.org/10.1104/pp.105.06374.

39. Libault M, Thibivilliers S, Bilgin DD, Radwan O, Benitez M, Clough SJ, et al. Identification of four soybean reference genes for gene expression normalization. Plant Genome. 2008. https://doi.org/10.3835/plant genome2008.02.0091.

40. Jung M, Ramankulov A, Roigas J, Johannsen M, Ringsdorf M, Kristiansen $G$, et al. In search of suitable reference genes for gene expression studies of human renal cell carcinoma by real-time PCR. BMC Mol Biol. 2007;8:47. https://doi.org/10.1186/1471-2199-8-47.

41. Rho H-W, Lee B-C, Choi E-S, Choi I-J, Lee Y-S, Goh S-H. Identification of valid reference genes for gene expression studies of human stomach cancer by reverse transcription-qPCR. BMC Cancer. 2010;10:240. https:// doi.org/10.1186/1471-2407-10-240.

42. Narsai R, Ivanova A, Ng S, Whelan J. Defining reference genes in Oryza sativa using organ, development, biotic and abiotic transcriptome datasets. BMC Plant Biol. 2010;10:56. https://doi.org/10.1186/ 1471-2229-10-56.

43. Manoli A, Sturaro A, Trevisan S, Quaggiotti S, Nonis A. Evaluation of candidate reference genes for qPCR in maize. J Plant Physiol. 2012;169:80715. https://doi.org/10.1016/j.jplph.2012.01.019.

44. Cheng Y, Bian W, Pang X, Yu J, Ahammed GJ, Zhou G, et al. Genomewide identification and evaluation of reference genes for quantitative RT-PCR analysis during tomato fruit development. Front Plant Sci. 2017. https://doi.org/10.3389/fpls.2017.01440.

45. Müller OA, Grau J, Thieme S, Prochaska H, Adlung N, Sorgatz A, et al. Genome-wide identification and validation of reference genes in infected tomato leaves for quantitative RT-PCR analyses. PLoS ONE. 2015;10: e0136499. https://doi.org/10.1371/journal.pone.0136499.

46. Long $X-Y$, Wang J-R, Ouellet $T$, Rocheleau H, Wei Y-M, Pu Z-E, et al. Genome-wide identification and evaluation of novel internal control genes for Q-PCR based transcript normalization in wheat. Plant Mol Biol. 2010;74:307-11. https://doi.org/10.1007/s11103-010-9666-8.

47. Zhao J, Yang F, Feng J, Wang Y, Lachenbruch B, Wang J, et al. Genomewide constitutively expressed gene analysis and new reference gene selection based on transcriptome data: a case study from poplar/canker disease interaction. Front Plant Sci. 2017. https://doi.org/10.3389/ fpls.2017.01876.

48. Gutierrez L, Mauriat M, Gunin S, Pelloux J, Lefebvre J-F, Louvet R, et al. The lack of a systematic validation of reference genes: a serious pitfall undervalued in reverse transcription-polymerase chain reaction (RTPCR) analysis in plants. Plant Biotechnol J. 2008;6:609-18. https://doi. org/10.1111/j.1467-7652.2008.00346.x.

49. Udvardi MK, Czechowski T, Scheible W-R. Eleven golden rules of quantitative RT-PCR. Plant Cell. 2008;20:1736-7. https://doi.org/10.1105/tpc. 108.061143.

50. Bustin SA, Benes V, Garson JA, Hellemans J, Huggett J, Kubista M, et al. The MIQE guidelines: minimum information for publication of 
quantitative real-time PCR experiments. Clin Chem. 2009;55:611-22. https://doi.org/10.1373/clinchem.2008.112797.

51. Selim M, Legay S, Berkelmann-Löhnertz B, Langen G, Kogel K-H, Evers D. Identification of suitable reference genes for real-time RT-PCR normalization in the grapevine-downy mildew pathosystem. Plant Cell Rep. 2012;31:205-16. https://doi.org/10.1007/s00299-011-1156-1.

52. Monteiro F, Sebastiana M, Pais MS, Figueiredo A. Reference gene selection and validation for the early responses to downy mildew infection in susceptible and resistant Vitis vinifera cultivars. PLOS ONE. 2013;8: e72998. https://doi.org/10.1371/journal.pone.0072998.

53. Borges AF, Ferreira RB, Monteiro S. Transcriptomic changes following the compatible interaction Vitis vinifera-Erysiphe necator. Paving the way towards an enantioselective role in plant defence modulation. Plant Physiol Biochem. 2013;68:71-80. https://doi.org/10.1016/j.plaphy. 2013.03.024.

54. Maia M, Ferreira AEN, Nascimento R, Monteiro F, Traquete F, Marques $A P$, et al. Integrating metabolomics and targeted gene expression to uncover potential biomarkers of fungal/oomycetes-associated disease susceptibility in grapevine. Sci Rep. 2020;10:15688. https://doi.org/10. 1038/s41598-020-72781-2.

55. Upadhyay A, Jogaiah S, Maske SR, Kadoo NY, Gupta VS. Expression of stable reference genes and SPINDLY gene in response to gibberellic acid application at different stages of grapevine development. Biol Plant. 2015;59:436-44. https://doi.org/10.1007/s10535-015-0521-2.

56. Faccioli P, Ciceri GP, Provero P, Stanca AM, Morcia C, Terzi V. A combined strategy of "in silico" transcriptome analysis and web search engine optimization allows an agile identification of reference genes suitable for normalization in gene expression studies. Plant Mol Biol. 2007;63:67988. https://doi.org/10.1007/s11103-006-9116-9.

57. Paolacci AR, Tanzarella OA, Porceddu E, Ciaffi M. Identification and validation of reference genes for quantitative RT-PCR normalization in wheat. BMC Mol Biol. 2009;10:11. https://doi.org/10.1186/ 1471-2199-10-11.

58. Mu J, Chen L, Gu Y, Duan L, Han S, Li Y, et al. Genome-wide identification of internal reference genes for normalization of gene expression values during endosperm development in wheat. J Appl Genet. 2019;60:23341. https://doi.org/10.1007/s13353-019-00503-0.

59. Yim AK-Y, Wong JW-H, Ku Y-S, Qin H, Chan T-F, Lam H-M. Using RNA-Seq data to evaluate reference genes suitable for gene expression studies in soybean. PLoS ONE. 2015;10: e0136343. https://doi.org/10.1371/journal. pone. 0136343 .

60. Lin F, Jiang L, Liu Y, Lv Y, Dai H, Zhao H. Genome-wide identification of housekeeping genes in maize. Plant Mol Biol. 2014;86:543-54. https:// doi.org/10.1007/s11103-014-0246-1.

61. Smitha PK, Vishnupriyan K, Kar AS, Anil Kumar M, Bathula C, Chandrashekara KN, et al. Genome wide search to identify reference genes candidates for gene expression analysis in Gossypium hirsutum. BMC Plant Biol. 2019;19:405. https://doi.org/10.1186/s12870-019-1988-3.

62. Liu S, Cai P, Hou N, Piao X, Wang H, Hung T, et al. Genome-wide identification and characterization of a panel of house-keeping genes in Schistosoma japonicum. Mol Biochem Parasitol. 2012;182:75-82. https:// doi.org/10.1016/j.molbiopara.2011.12.007.

63. Durrenberger PF, Fernando FS, Magliozzi R, Kashefi SN, Bonnert TP, Ferrer $\mathrm{l}$, et al. Selection of novel reference genes for use in the human central nervous system: a BrainNet Europe study. Acta Neuropathol. 2012;124:893-903. https://doi.org/10.1007/s00401-012-1027-z.

64. Gamm M, Héloir M-C, Kelloniemi J, Poinssot B, Wendehenne D, Adrian $M$. Identification of reference genes suitable for qRT-PCR in grapevine and application for the study of the expression of genes involved in pterostilbene synthesis. Mol Genet Genom. 2011;285:273-85. https:// doi.org/10.1007/s00438-011-0607-2.

65. Coito JL, Rocheta M, Carvalho L, Amâncio S. Microarray-based uncovering reference genes for quantitative real time PCR in grapevine under abiotic stress. BMC Res Notes. 2012;5:220. https://doi.org/10.1186/ 1756-0500-5-220.

66. González-Agüero M, García-Rojas M, Di Genova A, Correa J, Maass A Orellana A, et al. Identification of two putative reference genes from grapevine suitable for gene expression analysis in berry and related tissues derived from RNA-Seq data. BMC Genom. 2013;14:878. https:// doi.org/10.1186/1471-2164-14-878.
67. Wei T-L, Wang H, Pei M-S, Liu H-N, Yu Y-H, Jiang J-F, et al. Identification of optimal and novel reference genes for quantitative real-time polymerase chain reaction analysis in grapevine. Aust J Grape Wine Res. 2021. https://doi.org/10.1111/ajgw.12483.

68. Martelli GP. An overview on grapevine viruses, viroids and the diseases they cause. In: Meng B, Martelli GP, Golino D, Fuchs M, editors. Grapevine viruses: molecular biology, diagnostics and management. Cham: Springer International Publishing AG; 2017. p. 31-46.

69. Martelli GP. Directory of virus and virus-like diseases of the grapevine and their agents. J Plant Pathol. 2014;96:1-136.

70. Song Y, Hanner RH, Meng B. Probing into the effects of grapevine leafroll-associated viruses on the physiology, fruit quality and gene expression of grapes. Viruses. 2021;13:593. https://doi.org/10.3390/ v13040593.

71. Naidu R, Rowhani A, Fuchs M, Golino D, Martelli GP. Grapevine leafroll: a complex viral disease affecting a high-value fruit crop. Plant Dis. 2014;98(9):1172-85.

72. Naidu RA, Maree HJ, Burger JT. Grapevine leafroll disease and associated viruses: a unique pathosystem. Annu Rev Phytopathol. 2015;53:613-34. https://doi.org/10.1146/annurev-phyto-102313-045946.

73. Atallah SS, Gomez MI, Fuchs MF, Martinson TE. Economic impact of grapevine leafroll disease on Vitis vinifera cv. Cabernet franc in finger lakes vineyards of New York. Am J Enol Vitic. 2012;63:73-9. https://doi. org/10.5344/ajev.2011.11055.

74. Guidoni S, Mannini F, Ferrandino A, Argamante N, Di Stefano R. Effect of virus status on leaf and berry phenolic compounds in two wine grapevine Vitis vinifera cultivars. Acta Hortic. 2000;526:445-52. https://doi.org/ 10.17660/ActaHortic.2000.526.49.

75. Singh Brar H, Singh Z, Swinny E, Cameron I. Girdling and grapevine leafroll associated viruses affect berry weight, colour development and accumulation of anthocyanins in 'Crimson Seedless' grapes during maturation and ripening. Plant Sci. 2008;175:885-97. https://doi.org/10. 1016/j.plantsci.2008.09.005.

76. Lee J, Martin RR. Influence of grapevine leafroll associated viruses (GLRaV-2 and -3) on the fruit composition of Oregon Vitis vinifera L. cV. Pinot noir: phenolics. Food Chem. 2009;1 12:889-96. https://doi.org/10. 1016/j.foodchem.2008.06.065.

77. Bertamini M, Nedunchezhian N. Leaf age effects on chlorophyll, Rubisco, photosynthetic electron transport activities and thylakoid membrane protein in field grown grapevine leaves. J Plant Physiol. 2002;159:799-803. https://doi.org/10.1078/0176-1617-0597.

78. Parry C, Blonquist JM, Bugbee B. In situ measurement of leaf chlorophyll concentration: analysis of the optical/absolute relationship. Plant Cell Environ. 2014;37:2508-20. https://doi.org/10.1111/pce.12324.

79. Coombe BG. Adoption of a system for identifying grapevine growth stages. Aust J Grape Wine Res. 1995;1:100-10.

80. Dry P., Coombe BG. Viticulture volume 1-resources. 2nd edition. Winetitles; 2004. https://www.awri.com.au/wp-content/uploads/grape growth.pdf.

81. Xiao H, Kim W-S, Meng B. A highly effective and versatile technology for the isolation of RNAs from grapevines and other woody perennials for use in virus diagnostics. Virol J. 2015;12:171. https://doi.org/10.1186/ s12985-015-0376-3.

82. Krueger F. Trim Galore! Babraham Bioinformatics. 2012. https://www. bioinformatics.babraham.ac.uk/projects/trim_galore/. Accessed 22 Jan 2021.

83. Andrews S. FastQC. Babraham Bioinformatics. 2010. https://www.bioin formatics.babraham.ac.uk/projects/fastqc/. Accessed 22 Jan 2020.

84. Jaillon O, Aury JM, Noel B, Policriti A, Clepet C, Casagrande A, et al. The grapevine genome sequence suggests ancestral hexaploidization in major angiosperm phyla. Nature. 2007;449:463-7. https://doi.org/10. 1038/nature06148.

85. Patro R, Duggal G, Love MI, Irizarry RA, Kingsford C. Salmon provides fast and bias-aware quantification of transcript expression. Nat Methods. 2017;14:417-9. https://doi.org/10.1038/nmeth.4197.

86. Li Y, Zhang L, Li R, Zhang M, Li Y, Wang H, et al. Systematic identification and validation of the reference genes from 60 RNA-Seq libraries in the scallop Mizuhopecten yessoensis. BMC Genom. 2019;20:288. https://doi. org/10.1186/s12864-019-5661-X. 
87. Dennis G, Sherman BT, Hosack DA, Yang J, Gao W, Lane HC, et al. DAVID: database for annotation, visualization, and integrated discovery. Genome Biol. 2003;4:P3.

88. Pfaffl MW, Tichopad A, Prgomet C, Neuvians TP. Determination of stable housekeeping genes, differentially regulated target genes and sample integrity: BestKeeper-excel-based tool using pair-wise correlations. Biotechnol Lett. 2004;26:509-15. https://doi.org/10.1023/B:BILE.00000 19559.84305.47

89. Ye J, Coulouris G, Zaretskaya I, Cutcutache I, Rozen S, Madden TL. Primer-BLAST: a tool to design target-specific primers for polymerase chain reaction. BMC Bioinform. 2012;13:134. https://doi.org/10.1186/ 1471-2105-13-134.

90. Thomas PD. PANTHER: a library of protein families and subfamilies indexed by function. Genome Res. 2003;13:2129-41. https://doi.org/10. 1101/gr.772403.

91. Chan P-L, Rose RJ, Abdul Murad AM, Zainal Z, Leslie Low E-T, Ooi LC-L, et al. Evaluation of reference genes for quantitative real-time PCR in oil palm elite planting materials propagated by tissue culture. PLoS ONE. 2014;9: e99774. https://doi.org/10.1371/journal.pone.0099774.

92. Yin Z, Xie F, Michalak K, Zhang B, Zimnoch-Guzowska E. Reference gene selection for miRNA and mRNA normalization in potato in response to potato virus Y. Mol Cell Probes. 2021;55: 101691. https://doi.org/10. 1016/j.mcp.2020.101691.

93. Lai C, Pan H, Huang X, Fan L, Duan C, Li S. Validation of reference genes for gene expression analysis of response to anthocyanin induction in cell cultures of Vitis davidii (Rom. Caill.) Foëx. In Vitro Cell Dev Biol Plant. 2018;54:642-57. https://doi.org/10.1007/s11627-018-9937-7.

94. Zuhar LM, Madihah AZ, Ahmad SA, Zainal Z, Idris AS, Shaharuddin NA. Determination of reference genes for normalisation of gene expression study of Ganoderma-infected oil palms. J Oil Palm Res. 2019. https:// doi.org/10.21894/jopr.2019.0051

95. Pfaff MW. A new mathematical model for relative quantification in real-time RT-PCR. Nucleic Acids Res. 2001;29:45e-45. https://doi.org/10. 1093/nar/29.9.e45.

96. Xu H, Bao J-D, Dai J-S, Li Y, Zhu Y. Genome-wide identification of new reference genes for $\mathrm{QRT}$-PCR normalization under high temperature stress in rice endosperm. PLoS ONE. 2015;10: e0142015. https://doi.org/ 10.1371/journal.pone.0142015.

97. Hoang VLT, Tom LN, Quek X-C, Tan J-M, Payne EJ, Lin LL, et al. RNA-seq reveals more consistent reference genes for gene expression studies in human non-melanoma skin cancers. PeerJ. 2017;5: e3631. https://doi. org/10.7717/peerj.3631.

98. Huang X, Li S, Zhan A. Genome-wide identification and evaluation of new reference genes for gene expression analysis under temperature and salinity stresses in Ciona savignyi. Front Genet. 2019. https://doi. org/10.3389/fgene.2019.00071.

99. Glare EM. beta-Actin and GAPDH housekeeping gene expression in asthmatic airways is variable and not suitable for normalising mRNA levels. Thorax. 2002;57:765-70. https://doi.org/10.1136/thorax.57.9.765.

100. Dheda K, Huggett JF, Chang JS, Kim LU, Bustin SA, Johnson MA, et al. The implications of using an inappropriate reference gene for realtime reverse transcription PCR data normalization. Anal Biochem. 2005:344:141-3. https://doi.org/10.1016/j.ab.2005.05.022.
101. Schmidt SM, Panstruga R. Cytoskeleton functions in plant-microbe interactions. Physiol Mol Plant Pathol. 2007;71:135-48. https://doi.org/ 10.1016/j.pmpp.2008.01.001.

102. Zee F, Gonsalves D, Goheen A, Kim KS, Pool R, Lee RF. Cytopathology of leafroll diseased grapevines and the purification and serology of associated closteroviruslike particles. Phytopathology. 1987;77:1427-34.

103. Kim KS, Gonsalves D, Teliz D, Lee KW. Ultrastructure and mitochondrial vesiculation associated with closteroviruslike particles in leafroll-diseased grapevines. Phytopathology. 1989;79:357-60. https://doi.org/10. 1094/Phyto-79-357.

104. Faoro F. Cytopathology of closteroviruses and trichoviruses infecting grapevines. In: Filamentous viruses of woody plants. Trivandrum: Research Signpost; 1997. p. 29-47.

105. Bustin S. Absolute quantification of mRNA using real-time reverse transcription polymerase chain reaction assays. J Mol Endocrinol. 2000;25:169-93. https://doi.org/10.1677/jme.0.0250169.

106. Rasheed S, Bashir K, Kim J-M, Ando M, Tanaka M, Seki M. The modulation of acetic acid pathway genes in Arabidopsis improves survival under drought stress. Sci Rep. 2018;8:7831. https://doi.org/10.1038/ s41598-018-26103-2.

107. Jia T, Le B. RNA stability measurements using RT-qPCR in Arabidopsis seedlings. Bio-protocol. 2020. https://doi.org/10.21769/BioProtoc.3680.

108. Cao J, Li M, Chen J, Liu P, Li Z. Effects of MeJA on Arabidopsis metabolome under endogenous JA deficiency. Sci Rep. 2016;6:37674. https:// doi.org/10.1038/srep37674.

109. Kozera B, Rapacz M. Reference genes in real-time PCR. J Appl Genet. 2013;54:391-406. https://doi.org/10.1007/s13353-013-0173-x.

110. Akbudak MA, Filiz E. Genome-wide investigation of proline transporter (ProT) gene family in tomato: bioinformatics and expression analyses in response to drought stress. Plant Physiol Biochem. 2020;157:13-22. https://doi.org/10.1016/j.plaphy.2020.10.004.

111. Cui J, Jiang N, Hou X, Wu S, Zhang Q, Meng J, et al. Genome-wide identification of IncRNAs and analysis of ceRNA networks during tomato resistance to Phytophthora infestans. Phytopathology. 2020;110:456-64. https://doi.org/10.1094/PHYTO-04-19-0137-R.

112. Teixeira da Silva JA, Hidvégi N, Gulyás A, Dobránszki J. mRNA transcription profile of potato (Solanum tuberosum L.) in response to explant cutting. Plant Cell Tissue Organ Cult. 2019;138:143-52. https://doi.org/ 10.1007/s11240-019-01613-7.

113. Chang M-M, Li A, Feissner R, Ahmad T. RT-qPCR demonstrates lightdependent AtRBCS1A and AtRBCS3B mRNA expressions in Arabidopsis thaliana leaves. Biochem Mol Biol Educ. 2016;44:405-11. https://doi. org/10.1002/bmb.20959.

114. Yüzbaşığlu A, Onbaşılar I, Kocaefe Ç, Özgüç M. Assessment of housekeeping genes for use in normalization of real time PCR in skeletal muscle with chronic degenerative changes. Exp Mol Pathol. 2010;88:326-9. https://doi.org/10.1016/j.yexmp.2009.12.007.

\section{Publisher's Note}

Springer Nature remains neutral with regard to jurisdictional claims in published maps and institutional affiliations.

Ready to submit your research? Choose BMC and benefit from

- fast, convenient online submission

- thorough peer review by experienced researchers in your field

- rapid publication on acceptance

- support for research data, including large and complex data types

- gold Open Access which fosters wider collaboration and increased citations

- maximum visibility for your research: over 100M website views per year

At $\mathrm{BMC}$, research is always in progress.

Learn more biomedcentral.com/submissions 